\title{
PREVENCIÓN Y TRATAMIENTO \\ PREVENCIÓN Y TRATAMIENTO EN EL ÁMBITO PENITENCIARIO: LAS \\ MUJERES RECLUSAS DROGODEPENDIENTES EN ESPAÑA ${ }^{1}$
}

\author{
PREVENTION AND TREATMENT \\ IN PRISON LAW: WOMEN PRISONERS DRUG DEPENDENCE IN SPAIN
}

\author{
PREVENÇÃO E TRATAMENTO \\ NAS PRISÕES: RECLUSAS TOXICODEPENDENTES EM ESPANHA
}

\author{
Francisco José Del Pozo Serrano
}

UnIVERSIDAD DEL NORTE, COlOMBIA

RESUMEN: El tratamiento penitenciario de drogodependencias para mujeres ha sido tradicionalmente genérico (el aplicado para la mayoría masculina penitenciaria) y con pocos estudios diferenciales empíricos a nivel español. Esta investigación plantea a partir de los marcos normativos y la situación expresada por los organismos especializados, estudiar algunos de los factores de riesgo y de protección principales de las reclusas drogodependientes en relación a los programas de tratamiento y los procesos de recuperación a fin de realizar propuestas de acción específicas. La investigación es multimétodo, insertada dentro del Proyecto l+D+l denominado "Mujeres reclusas drogodependientes y su reinserción social. Estudio socioeducativo y propuestas de acción" [EDU2009-13408], con una muestra nacional en segundo y tercer grado (Administración General del Estado y Comunidad de Cataluña), correspondiente aproximadamente al 15\% de las mujeres reclusas en el panorama nacional. Se han obtenido 538 cuestionarios válidos, 61 entrevistas semi-estructuradas, a los cuales aplicaron, por un lado, métodos de análisis informáticos y programas específicos para los datos cuantitativos (SPSS, V. 15 y 20) y métodos de análisis de contenido para los datos cualitativos. El análisis se ha realizado antes y durante el internamiento, a partir de cuatro perfiles de mujeres reclusas (AA: adictas activas (8'20 \%), EX: ex adictas (EX: $67^{\prime} 21 \%$ ), NA: no adictas (NA: 14,75\%) y PMM (9,84\%): adictas en programas de mantenimiento de metadona).

Entre los resultados principales encontramos como factores de riesgo destacados en relación al tratamiento que las mujeres ex adictas no participan, por lo general, en programas de prevención de recaídas. Esta realidad supone un importante problema puesto que casi un $70 \%$ de las mujeres son ex consumidoras. Existe un número de mujeres que no participan en los programas por desinformación, desconfianza y compatibilidad con otras actividades o existe una percepción de discriminación de género en el acceso y 
permanencia de las mujeres en los programas en relación a los hombres. En los factores principales de protección encontramos que la mayoría de las mujeres tienen las presiones familiares como una motivación para acceder a programas y que en algunos de los casos la situación de maternidad o ciertos factores personales, fueron definitivos para el acceso. Finalmente, se propone el modelo PROSO -MD (Programa Socioeducativo para mujeres drogodependientes) para que sea implementado en el ámbito penitenciario según perfiles de consumo a partir de la adecuación a las características y realidades de las mujeres, concretando a partir de una propuesta específica para mujeres ex adictas.

PALABRAS CLAVE: Prisión, drogodependencias, género, prevención, tratamiento.

ABSTRACT: The penitentiary drug dependence treatment for women has been traditionally generic (applied for most masculine penitentiary) and with few differentiating empiric studies in an spanish level.

Based on a regulatory framework, this research focuses on the study of the main elements of risk and protection implied in the relation between the drug dependant female prisoners and the treatment programs, as well as the recovery processes, in order to propose specific actions.

The research has a multimethod approach, inserted within the Project 1+D+| named "Mujeres reclusas drogodependientes y su reinserción social. Estudio socioeducativo y propuestas de acción" [EDU200913408], with a national sample of second and third degree (Central Government and Community of Catalonia), corresponding to an estimate of $15 \%$ of the female prisoners nationally. 538 valid questionnaires, 61 semi-structured interviews has been obtained, in which informatic analytical methods, specific programs for quantitative data (SPSS, V. 15 y 20), and analytical content methods for qualitative data has been applied. The analysis has been developed before and after the internment, including four profiles of female prisioners (AA: Active addicted (8'20\%), EX: ex addicted (EX: 67'21\%), NA: non addicted (NA: $14.75 \%$ ) and PMM (9.84\%) addicted within methadone maintenance programs ).

Among the main results found, it is relevant to mention the elements of risk related to the absence of participation of ex addicted women in relapse prevention programs. In fact, this is a relevant issue since $70 \%$ of the women are ex addicted. There is a large number of women not receiving any treatment in prision and not participating in any program due to lack of information, mistrust and overlap with other activities. Aditionally, theres is a perception of gender discrimination towards the access and permanece of women in the programs, compared with men. Also, within the main elements of protection, it has been found that most women access a program motivated by family pressure, and in some cases situations such as motherhood and certain personal health issues were determinant factors for a women to access a program.

Finally, a model PROSO _MD (Socio-educational Program for Drug Dependant Women) according to use pattern is proposed to be implemented in a penitentiary field, adapted to the characteristics and realities of the women implied and developing specific a proposal for ex addicted women.

KEYWORDS: prison, drug addiction, gender, prevention, treatment.

RESUMO: Tratamento medicamentoso prisão para as mulheres é tradicionalmente genérico (aplicado para o macho prisão maioria) e alguns estudos empíricos diferenciais de nível de espanhol. Esta pesquisa surge a partir dos marcos regulatórios ea situação expressa pelas agências especializadas, para estudar alguns dos fatores de risco e proteção de grandes reclusos toxicodependentes em relação aos programas de processos de tratamento e recuperação, a fim de apresentar propostas ação específica. A pesquisa é multimethod, inserido no Projecto I + D intitulado “ Mujeres reclusas drogodependientes y su reinserción social. Estudio socioeducativo y propuestas de acción "[EDU2009-13408], com uma amostra nacional em segundo e terceiro grau (Governo Geral e Comunidade da Catalunha), correspondendo a aproximadamente 15\% das mulheres presas no cenário nacional. Obtivemos 538 questionários válidos, 61 entrevistas semi-estru-

[ 174 ] FRANCISCO JOSÉ DEL POZO SERRANO

SIPS - PEDAGOGIA SOCIAL. REVISTA INTERUNIVERSITARIA [1139-1723 (2015) 26, 173-199] TERCERA ÉPOCA 
turadas para a qual aplicada, em primeiro lugar, os métodos de análise de computador e programas específicos para os dados quantitativos (SPSS, V. 15, 20) e os métodos de análise de conteúdo dados qualitativos. A análise foi realizada antes e durante a internação de quatro perfis de mulheres presas (AA: Ativo viciado (8'20\%), EX: ex viciado (EX: 67'21\%), NA: não viciado (NA: 14,75\%) e PMM (9,84\%) viciados em programas de manutenção com metadona).

Os principais resultados são fatores de risco como liderança em relação ao tratamento de mulheres ex viciados não são, em geral, em programas de prevenção de recaída. Este é realmente um grande problema, já que quase $70 \%$ das mulheres são ex-consumidores. Há um número de mulheres que participam dos programas devido à desinformação, desconfiança e compatibilidade com outras atividades ou se houver uma percepção de discriminação de gênero no acesso e retenção de mulheres nos programas em relação aos homens. Nas principais fatores de proteção descobriu que a maioria das mulheres tem a pressão da família como uma motivação para programas de acesso e, em alguns casos, o parto ou de certos fatores pessoais foram decisivos para o acesso. Finalmente, o modelo Proso -MD (Programa para mulheres Sócio-dependentes) é proposto para ser implementado em prisões como perfis de consumo de adaptarse às características e realidades de mulheres, de especificação de uma proposta específica mulheres viciadas ex.

PALAVRAS-CHAVE: prisão, dependência de drogas, gênero, prevenção, tratamento.

\section{Introducción}

La normativa referente a las drogodependencias en el ámbito penitenciario de la Administración General del Estado (AGE), en el caso de las personas internadas consumidoras en activo, plantea una atención especializada de las personas con problemas de consumo de drogas recogidas en el artículo 116 del Reglamento Penitenciario (RP) (IIPP, 2012):

En el no 1 del artículo, se evidencia la universalidad del acceso a los programas de atención de drogas para todo/a interno/a con dependencia a sustancias y con independencia de la situación penal o penitenciaria. El no 2, hace referencia dentro de la planificación estratégica y operativa que se desarrolla en la AGE y en cada centro penitenciario. Supone la adherencia de los programas de intervención a la política general del Ministerio de Sanidad y a los planes generales de drogas y su planificación normativa. Desde ahí, existe una potenciación de colaboración con las entidades especializadas y con el Tercer Sector. Esta posibilidad crea un canal de cogestión de la administración penitenciaria con las instituciones y redes sociales favoreciendo una cobertura más amplia, como ocurre con entidades como Proyecto Hombre, Fundación Atenea o Cruz Roja (Del Pozo, Añaños \& García, 2013).

\section{Introduction}

The regulation referring to drug addiction in the field of prisons within the range of the General State Administration (GSA) in the case of prisoners being active consumers, proposes specialized attention towards people with drug consumption problems contained in Article 116 of Penitentiary Rules (PR) (IIPP, 2012):

In the $\mathrm{n} 01$ point of the article, the universality of the access to the drug care programs for all prisoners with substance dependence regardless of their criminal or prison situation is evidenced. The point no2 refers to the strategic and operational planning that takes place in the GSA and in each prison. It implies adherence of the intervention programs to the general policy of the Ministry of Health and general drug plans and their rule planning. From there, there is an enhancement of cooperation with the specialized agencies and the Third Sector. This possibility creates a channel of co-management of the prison administration with institutions and social networks favoring broader coverage, as with organizations like Man Project, Athena Foundation or the Red Cross (Del Pozo, Añaños \& García, 2013). 
La legislación plantea igualmente en su punto 3, que para la realización de programas permanentes relativos a drogodependencias, el centro directivo podrá disponer de departamentos específicos ubicados en diferentes áreas geográficas para evitar, en lo posible, el desarraigo social de los internos que sigan un programa en ellos.

Según la Secretaría General de Instituciones Penitenciarias (SGIP), el desarrollo de los programas de intervención en materia de drogodependencias está sustentado en tres tipos de equipos en cada centro (IIPP, 2010:188-189): la comisión GAD, el equipo sanitario, y el equipo técnico-GAD. La Comisión GAD, con funciones fundamentalmente de dirección y coordinación, es el equipo responsable de la aprobación, coordinación en la ejecución y evaluación del conjunto de programas preventivos, asistenciales y de reincorporación social del centro penitenciario. Presidida por la dirección del centro penitenciario, suele estar compuesta por la subdirección médica/personal, jefatura de los servicios médicos, subdirección de tratamiento y coordinación de los equipos Técnicos-GADs, además de la coordinación del resto de programas con internos/as drogodependientes.

El equipo técnico-GAD puede ser compuesto por: médico/a, psicólogo/a, educador/a y trabajador social. El equipo sanitario participa en actuaciones de prevención de la enfermedad, promoción de la salud, diagnóstico y tratamiento de enfermedades. El equipo sanitario del centro penitenciario realiza el diseño, ejecución y evaluación de programas sanitarios, el programa específico de intercambio de jeringuillas, y el de prescripción y dispensación de metadona, realizando así mismo las intervenciones en sobredosis, desintoxicación de sustancias de abuso y tratamiento.

Los programas desarrollados en Drogodependencias en prisión consisten principalmente en: 1) reducción de riesgos y daños, 2) deshabituación, 3) intervención sanitaria, y 4) intervención psicosocial, manifestándose claramente en el informe que los fines son "reducir los efectos nocivos a nivel sanitario, psicológico y social del consumo de drogas" así como, "La intervención psicosocial dirigida a la mejora en la competencia psicológica y social, siendo un elemento clave en el proceso de resocialización" (Ibídem: 189). En ningún caso se explicita que sea
The legislation also poses in point 3, that "for the realization of permanent programs for drug addiction, the management center may dispose of specific departments located in different geographic areas to avoid, where possible, the social uprooting of prisoners who follow a program in them.

According to the General Secretariat of Penitentiary Institutions (GSPI), the development of intervention programs in matters of drug dependence is based on three types of teams in each center (IIPP, 2010: 188-189): the GAD committee, the sanitary team, GAD and technical team. The GAD Commission, primarily with functions of management and coordination, is responsible for the approval, coordination of implementation and evaluation of all prevention, care and social reintegration programs within the penitentiary. Chaired by the management of the penitentiary, it is usually composed by the medical/personal subdirection, head of medical services, treatment subdirection and coordination of technicalGADs equipment as well as the coordination of the rest of the programs with other prisoners/drug dependent individuals.

The GAD technical team can be composed of: doctor, psychologist, educator and social worker. The sanitary team participates in activities related to disease prevention, health promotion, diagnosis and treatment of diseases. The prison's sanitary team performs the design, implementation and evaluation of health programs, the specific program of needle exchange and the program that involves prescribing and dispensing of methadone, also performing interventions in overdose cases, detoxification of abused substances and treatment with antagonists.

The programs developed in Addictions in prison consist mainly of: 1) reduction of risk and harm, 2) addiction cessation 3) sanitary intervention, and 4) psychosocial intervention, clearly demonstrating in the report that the aims are "to reduce the harmful effects of drug consumption at a sanitary, psychological and social level" and "The psychosocial intervention aimed at improving the psychological and social competence, being a key element in the process of resocialization " (Ibidem: 189). In no case it is made expli-

[ 176 ] FRANCISCO JOSÉ DEL POZO SERRANO 
necesario un aprendizaje basado en transformación educativa el que pueda potenciar nuevos hábitos y comportamientos prosociales, entendiéndose que el fundamento del cambio se produce mediante las disciplinas e intervenciones psicomédicas. Sin embargo ciertas tipologías de programas cuentan en muchos casos con clasificaciones de proyección socioeducativa. Los programas de drogas, en este sentido, son (IIPP, 2010): "programas sanitarios, las intervenciones de prevención, educación para la salud y mediadores en salud, el programa de intercambio de jeringuillas y el programa de tratamiento con metadona" (p.189). Podemos tener una panorámica general además de la transversalidad de la prevención de drogodependencias en los diferentes programas recogidos en la siguiente tabla (Tabla no1). Algunas de las últimas instrucciones penitenciarias respecto al tratamiento de drogas han sido la 4/2011 sobre tabaquismo, la 10/2014 sobre actuación en sobredosis o la 9/2014 sobre Organización y funcionamiento de las Unidades terapéuticas y educativas (IIPP, 2014).

Realizando una aproximación identificativa y cuantitativa de la atención en drogas en los informes generales encontramos que no se advierte una segregación por sexo en sus resultados de participación, siendo las siguientes entidades públicas y privadas las más significativas (IIPP, 2010):

Administración Pública: A nivel autonómico, la AGE tiene firmados 5 convenios generales que tienen actuaciones en materias de drogodependencias con Andalucía, Extremadura, Galicia, Madrid y Murcia, que recogen actuaciones en drogodependencias. Existen 3 convenios específicos en materia de drogodependencias suscritos con la Consejería de Sanidad de Castilla La Mancha (1999), con la Consejería de Sanidad y Bienestar Social de la ciudad de Ceuta (2003), y con la Consejería para la lgualdad y Bienestar Social de Andalucía (2005).

Entidades sin ánimo de Lucro: Existen 66 entidades sin ánimo de lucro con intervención intra o extrapenitenciaria que atienden y/o acogen a población penitenciaria. De todas ellas, si atendemos a la cobertura territorial donde participan, a la cabeza estaría Proyecto Hombre como la principal protagonista con 39 centros atendidos, seguidamente de Cruz Roja con 25 centros y la Fundación Atenea. Grupo CID con 9 centros, especialmente los cen- cit that it is necessary to have a learning transformation that can enhance new habits and prosocial behavior, meaning that the basis of change occurs through the disciplines and the psychomedical interventions. However certain types of programs count in many cases with classifications of socio-educational projection. In this sense, drug programs, are (IIPP, 2010): "sanitary programs, prevention interventions, health education and health mediators, the needle exchange program and the methadone treatment program" ( $p$.189). We can get a general overview plus the mainstreaming of drug prevention in the various programs listed in the following table (Table no 1). Some of the latest instructions regarding penitentiary drug treatment have been the 4/2011 on smoking, 10/2014 on performance in overdose or the $9 / 2014$ on the organization and operation of the therapeutic and educational units (IIPP, 2014).

Performing an identifying and quantitative approach for the attention on drugs in the general reports, it was found that sex segregation was not warned in their participation results, being the following the most significant public and private entities (IIPP, 2010):

Public Administration: On an autonomic level, the AGE has signed 5 general agreements that take actions in matters of drug addiction with Andalucía, Extremadura, Galicia, Madrid and Murcia, which take actions on drug addiction. There are 3 specific agreements in the matter of the drug dependency. There are subscriptions with the Ministry of Health of Castilla La Mancha (1999), with the Ministry of Health and Social Welfare of the City of Ceuta (2003), and the Ministry for Equality and Social Welfare of Andalucía (2005).

Non-Profit Entities: There are 66 non-profit entities with intra or extra-penitentiary intervention attending and/or hosting the prison population. Of these, if we consider the territorial coverage where they are involved, the Project Man would be head as the main protagonist with 39 centers being attended, then the Red Cross with 25 centers and Athena Foundation. CID Group with 9 centers, particularly the centers that are distributed in the autonomous regions of Castilla La Mancha and Madrid. 
Tabla 1. Tipos de programas donde existe transversalidad en relación a las drogodependencias

\begin{tabular}{|c|c|c|c|c|}
\hline $\begin{array}{l}\text { PROGRAMAS } \\
\text { DE ACOGIDA Y } \\
\text { MOTIVACIÓN }\end{array}$ & $\begin{array}{c}\text { PROGRAMAS } \\
\text { DE CARÁCTER } \\
\text { LÚDICO Y } \\
\text { RECREATIVO. }\end{array}$ & $\begin{array}{c}\text { PROGRAMAS } \\
\text { SOCIOCULTURALES }\end{array}$ & $\begin{array}{l}\text { PROGRAMAS } \\
\text { DE ACTIVIDADES } \\
\text { DEPORTIVAS }\end{array}$ & $\begin{array}{l}\text { PROGRAMAS DE } \\
\text { PREPACIÓN DE LA } \\
\text { VIDA EN LIBERTAD }\end{array}$ \\
\hline $\begin{array}{l}\text { Evaluación de in- } \\
\text { tervenciones higié- } \\
\text { nico-sanitarias y far- } \\
\text { macológicas que se } \\
\text { valoren como prio- } \\
\text { ritarias a partir de } \\
\text { los programas indi- } \\
\text { vidualizados de tra- } \\
\text { tamiento. Entre- } \\
\text { vista con } \\
\text { información especí- } \\
\text { fica sobre los diver- } \\
\text { sos programas de } \\
\text { intervención, los re- } \\
\text { quisitos de acceso } \\
\text { a los mismos, el res- } \\
\text { ponsable a quien } \\
\text { dirigirse, etc. Incor- } \\
\text { poración a los di- } \\
\text { versos programas. }\end{array}$ & $\begin{array}{l}\text { Programas de ca- } \\
\text { rácter lúdico y re- } \\
\text { creativo ofrecen } \\
\text { alternativas de } \\
\text { ocupación del } \\
\text { tiempo libre y me- } \\
\text { jora de competen- } \\
\text { cias personales. } \\
\text { Orientaciones a } \\
\text { Junta de Trata- } \\
\text { miento y los profe- } \\
\text { sionales del GAD, } \\
\text { a la hora de esta- } \\
\text { blecer los modelos } \\
\text { individualizados de } \\
\text { intervención o tra- } \\
\text { tamiento, deben } \\
\text { también tener en- } \\
\text { cuentra las necesi- } \\
\text { dades culturales y } \\
\text { deportivas del in- } \\
\text { terno/a y la oferta } \\
\text { del centro, elabo- } \\
\text { rando a partir de } \\
\text { ahí los programas } \\
\text { culturales y depor- } \\
\text { tivos. }\end{array}$ & $\begin{array}{l}\text { De Creación Cultural: } \\
\text { talleres de expresión } \\
\text { artística (pintura, cerá- } \\
\text { mica, fotografía, ma- } \\
\text { nualidades, encuader- } \\
\text { nación) y de } \\
\text { comunicación (radio, } \\
\text { video, teatro, música, } \\
\text { etc. De Difusión Cul- } \\
\text { tural: donde se pre- } \\
\text { tende intercambiar } \\
\text { experiencias con la } \\
\text { comunidad actuacio- } \\
\text { nes musicales, exposi- } \\
\text { ciones, muestras de } \\
\text { teatro, etc. De Forma- } \\
\text { ción y Motivación: } \\
\text { comprenden aquellas } \\
\text { actividades y cursos } \\
\text { que ayudan a valorar } \\
\text { y potenciar actitudes } \\
\text { positivas hacia su per- } \\
\text { sona y hacia el resto } \\
\text { del colectivo social. } \\
\text { Sobresalen activida- } \\
\text { des como animación a } \\
\text { la lectura, participa- } \\
\text { ción en concursos y } \\
\text { certámenes y progra- } \\
\text { mas específicos. }\end{array}$ & $\begin{array}{l}\text { De actividad física de } \\
\text { carácter recreativo: } \\
\text { cada interno/a debe } \\
\text { tener la opción de de- } \\
\text { sarrollar sus intereses } \\
\text { deportivos en el } \\
\text { marco de las activida- } \\
\text { des recreativas perso- } \\
\text { nales que prefiera. De } \\
\text { actividad física dirigida } \\
\text { a la competición: se } \\
\text { fomentará la competi- } \\
\text { ción oficial (federada), } \\
\text { además de organizar } \\
\text { campeonatos internos } \\
\text { y competiciones inter- } \\
\text { centros. Formación y } \\
\text { motivación deportiva: } \\
\text { se pretende implantar } \\
\text { la educación deportiva } \\
\text { mediante la creación } \\
\text { de las escuelas depor- } \\
\text { tivas. Las salidas pro- } \\
\text { gramadas, tanto cultu- } \\
\text { rales como deportivas, } \\
\text { juegan un papel fun- } \\
\text { damental. Cada cen- } \\
\text { tro tiene su propia } \\
\text { oferta de actividades } \\
\text { que, en ocasiones, se } \\
\text { llevan a cabo con la } \\
\text { colaboración de } \\
\text { ONGs, entidades pú- } \\
\text { blicas y privadas. }\end{array}$ & $\begin{array}{l}\text { Se contacta con todos } \\
\text { aquellos internos que } \\
\text { están realizando pro- } \\
\text { gramas de tratamiento } \\
\text { recogidos en la Comi- } \\
\text { sión GAD, y para quie- } \\
\text { nes se prevé que sal- } \\
\text { drán en libertad en un } \\
\text { plazo de nueve meses } \\
\text { a un año. A partir de } \\
\text { ahí comienzan una se- } \\
\text { rie de entrevistas indi- } \\
\text { viduales donde se } \\
\text { analizan las expectati- } \\
\text { vas, los proyectos y } \\
\text { los recursos, persona- } \\
\text { les y sociales con los } \\
\text { que cuenta el interno, } \\
\text { y se diseña de común } \\
\text { acuerdo un itinerario } \\
\text { de inserción. Una vez } \\
\text { concretada la diversi- } \\
\text { dad de requerimien- } \\
\text { tos, se organiza el ta- } \\
\text { ller, donde se } \\
\text { trabajarán en grupo } \\
\text { los contenidos comu- } \\
\text { nes a todos los partici- } \\
\text { pantes (normalmente } \\
\text { continuidad del trata- } \\
\text { miento en recursos } \\
\text { externos, las relacio- } \\
\text { nes familiares, bús- } \\
\text { queda de empleo y/o } \\
\text { formación, habilidades } \\
\text { sociales, etc.) y a nivel } \\
\text { individual todo aquello } \\
\text { que por su naturaleza } \\
\text { no tiene cabida en } \\
\text { otro espacio. }\end{array}$ \\
\hline
\end{tabular}

Fuente: Elaboración propia a partir de IIPP (2013). 
Table 1. Types of programs where there is mainstreaming in relation to drug addiction

\begin{tabular}{|c|c|c|c|c|}
\hline $\begin{array}{l}\text { WELCOMING } \\
\text { PROGRAMS AND } \\
\text { MOTIVATION }\end{array}$ & $\begin{array}{l}\text { PROGRAMS OF } \\
\text { EDUCATIONAL } \\
\text { AND RECREATIVE } \\
\text { CHARACTER }\end{array}$ & $\begin{array}{l}\text { SOCIO-CULTURAL } \\
\text { PROGRAMS }\end{array}$ & $\begin{array}{l}\text { SPORT ACTIVITIES } \\
\text { PROGRAMS }\end{array}$ & $\begin{array}{l}\text { PROGRAMS FOR THE } \\
\text { PREPARATION OF } \\
\text { LIFE IN FREEDOM }\end{array}$ \\
\hline $\begin{array}{l}\text { Evaluation of sani- } \\
\text { tary and pharmaco- } \\
\text { logical interven- } \\
\text { tions that are } \\
\text { valued as a priority } \\
\text { from the individua- } \\
\text { lized treatment } \\
\text { programs. } \\
\text { Interview with spe- } \\
\text { cific information } \\
\text { about the various } \\
\text { intervention pro- } \\
\text { grams, the require- } \\
\text { ments for access to } \\
\text { them, the person in } \\
\text { charge to turn to, } \\
\text { etc. } \\
\text { Incorporation into } \\
\text { the various pro- } \\
\text { grams. }\end{array}$ & $\begin{array}{l}\text { Programs of edu- } \\
\text { cational and recre- } \\
\text { ational character } \\
\text { offer alternatives } \\
\text { for occupation of } \\
\text { free time and im- } \\
\text { proving personal } \\
\text { skills. } \\
\text { Orientation to the } \\
\text { board of treatment } \\
\text { and GAD profes- } \\
\text { sionals, when esta- } \\
\text { blishing individuali- } \\
\text { zed models of } \\
\text { intervention or tre- } \\
\text { atment, the cultu- } \\
\text { ral and sport ne- } \\
\text { eds of the inmate } \\
\text { and the offer of } \\
\text { the center should } \\
\text { be taken into ac- } \\
\text { count, developing } \\
\text { from there the cul- } \\
\text { tural and sport } \\
\text { programs }\end{array}$ & $\begin{array}{l}\text { Cultural Creation: ar- } \\
\text { tistic expression } \\
\text { workshops (painting, } \\
\text { ceramics, photo- } \\
\text { graphy, crafts, binding) } \\
\text { and communication } \\
\text { (radio, video, theater, } \\
\text { music, etc. } \\
\text { Cultural Diffusion: } \\
\text { which aims to ex- } \\
\text { change experiences } \\
\text { with community, musi- } \\
\text { cal performances, ex- } \\
\text { hibitions, theater sam- } \\
\text { ples, etc. } \\
\text { Training and Motiva- } \\
\text { tion: include those ac- } \\
\text { tivities and courses } \\
\text { that help assess and } \\
\text { enhance positive atti- } \\
\text { tudes toward themsel- } \\
\text { ves and toward the } \\
\text { rest of the social } \\
\text { group. Excel activities } \\
\text { like reading promo- } \\
\text { tion, participation in } \\
\text { competitions and con- } \\
\text { tests and specific } \\
\text { programs. }\end{array}$ & $\begin{array}{l}\text { Physical activity of re- } \\
\text { creational character: } \\
\text { each intern should } \\
\text { have the option to de- } \\
\text { velop their sporting in- } \\
\text { terests within the fra- } \\
\text { mework of personal } \\
\text { recreation choice. } \\
\text { Physical activity aimed } \\
\text { at the competition: the } \\
\text { official competition } \\
\text { (federated) will be en- } \\
\text { couraged, besides or- } \\
\text { ganizing internal cham- } \\
\text { pionships and } \\
\text { inter-center competi- } \\
\text { tions. } \\
\text { Training and sport mo- } \\
\text { tivation: it is intended } \\
\text { to implement sports } \\
\text { education by creating } \\
\text { sports schools. The } \\
\text { field trips program- } \\
\text { med, both cultural and } \\
\text { of a sport kind play a } \\
\text { fundamental role. } \\
\text { Each center has its } \\
\text { own offer of activities } \\
\text { which sometimes are } \\
\text { carried out in collabo- } \\
\text { ration with NGOs, pu- } \\
\text { blic and private enti- } \\
\text { ties }\end{array}$ & $\begin{array}{l}\text { Contact is made with } \\
\text { all those inmates who } \\
\text { are doing treatment } \\
\text { programs contained in } \\
\text { the GAD Commission, } \\
\text { and those who are ex- } \\
\text { pected to come out in } \\
\text { freedom within nine } \\
\text { months to a year. } \\
\text { From there, a series of } \\
\text { individual interviews } \\
\text { begin, where expecta- } \\
\text { tions, projects and re- } \\
\text { sources, personal and } \\
\text { social, that the inmate } \\
\text { counts on are analy- } \\
\text { zed, and a common } \\
\text { agreement itinerary of } \\
\text { insertion is designed. } \\
\text { Upon completion of } \\
\text { the diversity of requi- } \\
\text { rements, the works- } \\
\text { hop is organized, } \\
\text { where all participants } \\
\text { will work in groups on } \\
\text { common contents } \\
\text { (usually continuity of } \\
\text { the treatment in exter- } \\
\text { nal resources, family } \\
\text { relationships, job se- } \\
\text { arch and/or training, } \\
\text { social skills, formation, } \\
\text { etc.) and on an indivi- } \\
\text { dual level, all that be- } \\
\text { cause of its nature has } \\
\text { no place in another } \\
\text { space. }\end{array}$ \\
\hline
\end{tabular}

Source: Compiled from IPP (2013) 
tros distribuidos en las Comunidades autónomas de Castilla La Mancha y Madrid.

Hay que tener en cuenta que la situación de crisis económica ha reducido, en parte, la participación de entidades en la comunidad social, repercutiendo claramente en estos últimos años en el ámbito penitenciario (Del Pozo \& Gil, 2012).

La investigación realizada busca, a partir de la realidad existente en la intervención penitenciaria en drogodependencias, estudiar algunos de los factores de riesgo y de protección principales de las reclusas drogodependientes en relación a los programas de tratamiento y los procesos de recuperación a fin de realizar propuestas de acción específicas.

Para este fin, se han estudiado según las clasificaciones realizadas por DSM IV, cuatro perfiles de reclusas en relación con el consumo de drogas, a fin de que los programas preventivos y de tratamiento puedan ser pertinentes, tenga en cuenta el enfoque diferencial de género y la perspectiva socioeducativa. Los diferentes grupos de mujeres que se han tenido en cuenta para el estudio:

- Adictas activas (AA): Consumidoras problemáticas de drogas ilegales, alcohol si es droga principal y de consumo diario, así como los fármacos sin receta. No entran en la definición el tabaco, los fármacos recetados y alcohol de uso, aunque estos se pueden analizar en cada caso.

- Adictas en PMM (MM): participantes en programas de mantenimiento de metadona.

- Ex adictas (EX): abstinentes de las sustancias definidas como drogas previamente.

- No adictas (NA): abstinentes totales o de consumos experimentales y no sostenidos el tiempo.

\section{Prevención y tratamiento en las prisiones españolas}

Dentro de todas las intervenciones en salud que se desarrollan en el medio penitenciario, existen tipologías de programas de tratamiento y deshabituación de drogas en Instituciones Penitenciarias, que se podría agrupar a nivel general en (IIPP, 2012):

- Prevención y educación para la salud: Dirigido a evitar el inicio del consumo y reducir conductas de riesgo.
Keep in mind that the economic crisis has partially reduced the participation of entities in the social community, clearly impacting during recent years in the penitentiary field (Del Pozo \& Gil, 2012).

From the existent reality in the penitentiary intervention on drug dependency, the research carried out seeks to study some of the main risk factors and protection of the female prisoners in relation to drug-addicts treatment programs and recovery processes to propose specific action programs.

To this end, we have studied according to the classifications made by DSM IV, four profiles of female prisoners in relation to drug consumption, so that prevention and treatment programs may be relevant. Consider the differential gender focus and the socio-educational perspective. The different groups of women who have been taken into account in the study are:

- Active Addicts (AA): Problematic consumers of illegal drugs, alcohol if it is the principal drug and of daily consumption, as well as the drugs without a prescription. Tobacco does not fall in the definition along with the prescription drugs and alcohol of use, although these can be analyzed in each case.

- Addicted to PMM (MM): participating in methadone maintenance programs.

- Ex addicted (EX): abstinent drug substances defined as previously.

- No addicted (NA): Total consumption abstinent experimental or unsustained time.

\section{Prevention and treatment in the spanish prisons}

Within all health interventions that develop in the penitentiary field, there are typologies of treatment programs and cessation of drug addiction in Penitentiary Institutions, which could be grouped in general terms in (IIPP, 2012).

- Prevention and education for health: Aimed at preventing initiation of consumption and reducing risky conduct.

[ 180 ] FRANCISCO JOSÉ DEL POZO SERRANO 
- Mantenimiento con metadona: Es un programa que, por ejemplo, se desarrolla para evitar los efectos nocivos a nivel sanitario, psicológico y social del consumo de heroína, contribuyendo al abandono de la vía inyectada para su consumo y evitando la transmisión de las enfermedades adquiridas por esa vía.

- Deshabituación en módulos terapéuticos: Programa que se desarrolla en dependencias específicas para conseguir periodos de abstinencia y una reordenación de la dinámica personal y social.

- Programa de reincorporación social: Contempla un proceso complejo de socialización y normalización, incluyendo la adquisición de habilidades y recursos, que debe responder a las necesidades personales del drogodependiente, tratando de apoyar su incorporación a la vida familiar y medio cultural, laboral y social, así como derivando a dispositivos comunitarios para continuar el tratamiento a la salida en libertad, y evitar así su marginación.

Desde una perspectiva socioeducativa podríamos exponer que se va desarrollando un nuevo modelo de intervención en SGIP, pero que debe profundizar en los enfoques educativos mediante la especialización de este enfoque preventivo (Socidrogalcohol, 2012). En el marco de las penas privativas de libertad este enfoque se centra principalmente en propuestas que eviten recaídas y reincidencia (Lipton, Falkin \& Wexler, 2000; Añaños, 2010), permitiendo una mayor y mejor inserción y superando la ineficacia o el abandono de los programas. La prevención, además, debe focalizarse desde las concepciones ecológicas e integrales. Estas dimensiones incorporan una superación y complementación del modelo médico-sanitario de intervención que abordaba los fenómenos de la drogodependencia de una perspectiva de la enfermedad, generando proyectos y acciones basados en la inclusión social, el desarrollo comunitario y los enfoques de promoción de la salud (Del Pozo, 2013). El concepto de prevención integral, se entiende desde este punto de vista como necesario e incorpora, por tanto, la dimensión sociocultural, las condiciones sociales, el género, lo emocional, etc. Esto significa que no únicamente o principalmente se determina y se
- Maintenance with Methadone: A program that, for example, is developed to prevent harmful effects on a sanitary, psychological and social level of heroin consumption, contributing to the abandonment of the intravenous route for consumption and preventing the transmission of diseases acquired in this way.

- Cessation in therapeutic modules: Program that is developed in specific units to get periods of abstinence and a reordering of personal and social dynamics.

- Social reintegration program: Beholds a complex process of socialization and normalization, including the acquisition of skills and resources to respond to the personal needs of drug addicts, trying to support their integration into family life, cultural, work, and social environment, as well as deriving to community devices to continue treatment upon their release to freedom, and by doing so, prevent their marginalization.

From a socio-educational perspective we could expose that it is being developed a new model of intervention in SGIP, but it should deepen in the educational approaches through specialization of this preventive approach (Socidrogalcohol, 2012). In the context of freedom deprivation sentences this approach mainly focuses on proposals to prevent relapse and recidivism (Lipton, Falkin and Wexler, 2000; Añaños, 2010), allowing greater and better integration and overcoming inefficiency or neglect of programs. Prevention should additionally focus from the ecological and holistic conceptions. These dimensions incorporate an improvement and complementation of the medical-sanitary intervention model that addressed the phenomena of drug addiction from a disease perspective, generating projects and actions based on social inclusion, community development and health promotion approaches (Del Pozo, 2013). The concept of holistic prevention is understood from this point of view as required, and has, therefore, the socio-cultural dimension, social conditions, the gender, the emotional component, etc. This means that not solely or primarily it is determined and approached the consumption from individual factors but also from the context and complex realities that surround the human being (Ayala \& Fornaguera, 1996). 
aborda el consumo y el tratamiento de drogas desde factores individuales sino desde los contextos y realidades complejas que envuelven al ser humano (Ayala \& Fornaguera, 1996).

Las intervenciones socioeducativas en drogodependencias se han conceptualizado desde diferentes tipos de programas de prevención (Pantoja \& Añaños, 2010:120). Si adaptamos esos programas a los perfiles de mujeres reclusas, podríamos situar las siguientes clasificaciones:

- Programas de prevención universal: Se trata de actuaciones dirigidas a la población general o a un grupo amplio de personas no identificadas sobre la base de ningún factor de riesgo individual o, si los hay, no son críticos. Estos programas son los que tendrían que ser desarrollados con las mujeres no adictas.

- Programas de prevención selectiva o programas adaptados a segmentos de la población: Según datos objetivos (aportados desde la epistemología u otro tipo de investigación) poseen factores comprobados de riesgo. Estos programas serían desarrollados con mujeres no consumidoras que pudieran tener por factores externos (de la historia familiar de consumo o de las parejas), internos en el centro (relación con otras compañeras consumidoras, etc.).

- Programas de prevención indicada: Población con consumos problemáticos de drogas y a la vez con otros problemas no menos graves de conductas delictivas o violentas, familiares o de exclusión social. Estos programas deberían ser desarrollados con mujeres tengan consumos prolongados. Por ejemplo, podrían estar dentro de esta tipología aunque no únicamente, mujeres que tuviesen como sustancias principales el cannabis, el alcohol o los psicofármacos, etc.

- Programas de prevención determinada: Dirigidos a aquellos individuos que viven definitivamente en el mundo del abuso de drogas, que han convertido a éstas en su vida y que son reacios- porque no pueden o no quieren- a abandonar su situación. Atendería a mujeres que tuvieran o hubieran mantenido unos consumos problemáticos con heroína y/o cocaína principalmente, o policonsumos y también las que se encontraran con programas de mantenimiento de metadona.
The socio-educational interventions in drug addiction have been conceptualized from different types of prevention programs (Pantoja \& Añaños, 2010: 120). If we adapt these programs to the profiles of the female prisoners, we could place the following classifications:

- Universal prevention programs: These are actions aimed at the general public or a large group of unidentified individuals on the basis of no individual risk factor or if there are, they are not critical. These programs are those that would have to be developed with non-addicted women.

- Selective prevention programs or adapted to segments of the population: According to objective data (provided from the epistemology or other research) the possess proven risk factors. These programs would be developed with female who are not consumers who might have by external factors (family history of consumption or couple consumption), prisoners at the center (with a relationship to other consumer partners, etc.).

- Indicated prevention programs: Population with problematic drug use as well as no less serious criminal or violent behaviors, family problems or social exclusion. These programs should be developed with women with prolonged consumption. For example, they could be within this typology but not only women that had as main substances cannabis, alcohol or psychoactive drugs, etc.

- Specific prevention programs: Aimed at those individuals who permanently live in the world of drug abuse, those that have made drugs a part of their lives and who refuse -because they can't or they don't want- to leave their situation. It would serve women who have or would have maintained a problematic use of heroin and/or cocaine primarily, or poli-consumption and also the ones that were found to be with methadone maintenance programs.

At the indicated and determined preventive programs, which are the ones where drug abusers are involved, usually two phases or approaches in treatment programs are configured: addiction detoxification and drug abuse cessation (NIDA, 2012). The

[ 182 ] FRANCISCO JOSÉ DEL POZO SERRANO 
En los programas preventivos indicados y determinados, que son en los que participan las personas drogodependientes, se configuran normalmente dos fases o enfoques dentro de los programas de tratamiento: la desintoxicación y la deshabituación del abuso de drogas (NIDA, 2012). La primera fase hace referencia a la intervención médico- psicológica del drogodependiente al aparecer el síndrome de abstinencia a consecuencia de no tomar drogas. La desintoxicación puede ser domiciliaria, ambulatoria y hospitalaria. En esta fase no existe una intervención directa y básica del personal agente educador.

La deshabituación, debe participar de la presencia profesional de agentes a nivel psicoterapéutico y socioeducativo de manera que se desarrollen aprendizajes personales de conocimiento personal, búsqueda de valores o estilos de vida; asunción de responsabilidades, fortalecimiento de autoestima y habilidades sociales. A nivel de recursos o espacios del tratamiento de la deshabituación podemos concretar: centros ambulatorios, comunidades terapéuticas o centros de día.

Otras medidas socioeducativas podrían estar encaminadas a la reflexión, información y formación que potencie la identificación de los aspectos y circunstancias que, desde la familia, pueden tener una influencia positiva en la prevención del consumo de drogas (FAD, 2013): Información sobre distintos tipos de sustancias consideradas como drogas, así como sobre los riesgos asociados a su consumo, conocimiento de pautas y orientaciones básicas acerca de cómo abordar situaciones de consumo problemático de drogas en la familia o desarrollo de capacidades para mejorar la convivencia familiar a través de la negociación de normas y límites; participación en el entorno social de la misma, así como de empleo positivo de ocio y tiempo libre, adopción de actitudes y la adquisición de habilidades relacionadas con un adecuado clima afectivo y de comunicación en la familia. En la deshabituación y desarrollo de acciones preventivas es adecuado proponer a la familia como agente de especial protagonismo donde se potencien dinámicas familiares (de todos sus miembros) para activar oportunidades para poder activar el proceso formativo y educativo de los/as hijos/as, desarrollar una convivencia "segura", fomento de factores protectores y mediación familiar. En de- first phase concerns the action of the drug-addict's medical and psychological intervention when withdrawal symptoms appear as a result of not consuming drugs. Detoxification can be at home, ambulatory and at the hospital. At this stage there is no direct and basic intervention of the personal educational agent.

During the cessation there should be participation of the professional presence of agents on a psychotherapeutic and socio-educational level so that personal learnings from personal knowledge are developed, as well as search for values or lifestyles, accountability, strengthening of self-esteem and social skills. On the level of resources or areas of treatment of addiction cessation we can find: outpatient centers, therapeutic communities or day centers.

Other educational measures may be directed towards reflection, information and training that enhances the identification of the issues and circumstances that, from the family area, can have a positive influence on prevention of drug consumption (FAD, 2013): Information on different types of substances considered as drugs, as well as the risks associated with their consumption, knowledge of basic guidelines on how to address situations of problematic drug use in the family or development of capacity to improve family life through the negotiation of rules and limits; participation in the social environment of the same, and positive use of leisure time, adoption of attitudes and acquisition of abilities related to a proper emotional environment and family communication skills. During the consumption cessation and development of preventive actions it is appropriate to propose the family as an agent of special importance where family dynamics (including all members) are enhanced to enable opportunities to activate the training and education process of the children, develop a "safe" coexistence, promotion of protective factors and family mediation. In short, the work focused on the family (family competence) (Orte, Ballester \& March, 2013). 
finitiva el trabajo de centrado en la familia (competencia familiar) (Orte, Ballester \& March, 2013).

\subsection{La prevención y el tratamiento en drogodepen- dencias desde el enfoque diferencial de género}

Los papeles sociales asignados a las mujeres, no sólo no son equivalentes a los de los hombres, sino que contribuyen a situarla, en mayor medida y junto con otros colectivos desfavorecidos que no disponen de una igualdad de oportunidades, en una auténtica situación de vulnerabilidad personal y social. Esto ya, por sí mismo, constituye un desequilibrio, una situación de riesgo determinada por un contexto social que podría estar en la base de la ocurrencia de conductas "inadaptadas" entre ellas el consumo de sustancias. Por otro lado, de la misma manera que el género determina lo que es socialmente deseable junto con los "deberes" y "obligaciones" esperadas, también establece, por género, una sanción derivada de la transgresión de dichos roles.

La valoración del uso de drogas no es igual si éste se realiza por hombres que por mujeres. Las mujeres, a menudo, se ven afectadas en mayor medida por la penalización social (estigmatización) que acompaña a su problema. Además de la importancia de los roles, la infancia y su protección, y como consecuencia el riesgo que para los hijos tiene o tendría el consumo por parte de las mujeres/madres, es un valor arraigado en el constructo social.

Las mujeres presentan factores de riesgo o protección específicamente femeninos referidos a (Urbano \& Arostegui, 2004:34):

- El sexo biológico y las consecuencias orgánicas o biológicas diferentes que acarrea el consumo.

- La maternidad. La posibilidad real o futura de ser madres.

- Las diferencias de género en cuanto a las expectativas de conducta, los papeles asignados y el rol tradicionalmente ocupado por la mujer, y de ahí, la sanción derivada de la ocurrencia de determinados comportamientos o actitudes que transgreden este rol.

En el caso de las que son madres, que es una mayoría de las mujeres reclusas (aproximadamente un 80\%) (García Vita \& Melendro Estefanía, 2013), la separación y ruptura del vínculo madre-hijo puede

\subsection{The prevention and treatment on drug-addic- tions from the gender differential perspective}

Social roles assigned to women, not only are not equivalent to those of men, but contribute to situate women, on a greater extent and with other disadvantaged groups that do not have equal opportunities, in a real situation of personal and social vulnerability. This is already, by itself, an imbalance, a situation of risk determined by a social context that could be the basis of the occurrence of "maladaptive" behaviors including substance consumption. On the other hand, in the same way that gender determines what is socially desirable with the "duties" and expected "obligations", it also states, by gender, a penalty arising from the violation of these roles.

The assessment of drug use is not the same if it is done by men than by women. Women are often more affected by the social penalization (stigma) that accompanies their problem. Besides the importance of roles, childhood and its protection, and consequently the risk that it is or could be for children to have the consumption by women/mothers, it is an established value in the social construct.

Women present specific female risk factors or protection factors referred to (Urbano \& Arostegui, 2004:34):

- The biological sex and the different organic or biological consequences that the consumption brings about.

- Maternity. The real or future possibility to be mothers.

- Gender differences in terms of expectations of conduct, assigned roles and the role traditionally occupied by women, and hence the penalty resulting from the occurrence of certain behaviors or attitudes that transgress this role.

In the case of those who are mothers, which is a majority of women prisoners (about 80\%) (García Vita \& Melendro Estefanía, 2013), separation and rupture of the mother-child bond can be one of the determining factors in abandonment of the rehabilitation programs. Instead, encouraging the maintenance of this bond and the accompanying of the children during the program has shown to be a positive determinant. As reality not tended enough, we

[ 184 ] FRANCISCO JOSÉ DEL POZO SERRANO 
ser uno de los factores determinantes en el abandono de los programas de rehabilitación. Por el contrario, fomentar el mantenimiento de ese vínculo y el acompañamiento de los/las hijos/as durante el programa se muestra positivamente determinante. Como realidad no atendida suficientemente, creemos imprescindible y prioritario no desarraigar la convivencia de las/los hijas/os menores, en los casos en los que la deshabituación/desintoxicación no perjudique el interés superior del menor a largo plazo. Son muchos los casos en los que los programas públicos o privados, no atienden a mujeres en comunidades terapéuticas, programas ambulatorios, centros de día, recursos residenciales, etc. donde puedan estar las y los menores con sus madres. Esta situación, agrava en algunos casos, la desestructuración familiar y escenarios de desamparo para la prole; así mismo, se refuerza la vulnerabilidad como factor de riesgo para las mujeres al no poder convivir con sus hijas/os.

También debe ser tenido en cuenta el fenómeno del tráfico de drogas y el consumo de sustancias desde la feminización de la pobreza que repercute en su proceso sociolaboral y socioeducativo (Del Pozo, Jiménez \& Turbi, 2013). En este sentido, es relevante analizar cómo influyen las parejas masculinas en el contacto de las mujeres con las drogas, así como los consumos iniciáticos y abusivos de las mismas que llevan a muchas de las mujeres a una posterior marginalización o exclusión social (Del Pozo \& Peláez, 2013).

Desde esta premisa, tendríamos que considerar imprescindible desarrollar enfoques preventivos e interventivos que justifiquen que el desequilibrio entre hombres y mujeres en la asunción de responsabilidades familiares, de los cuidados de menores y mayores de la familia, etc. inciden directamente en el consumo de psicofármacos por parte de las mujeres (Orte, 2008). Además, es necesario deconstruir la criminalización moralizante ejercida hacia las mujeres consumidoras, y la asociación de una mayor vulnerabilidad psicológica, trastornos de ansiedad, estrés o depresión, únicamente por el hecho de ser mujeres (Castaños \& Palop, 2007).

La dimensión socioeducativa, supone la integración de las mujeres drogodependientes en el desarrollo y participación comunitaria, previniendo la estigmatización de las mismas, así como trabajando consider it essential and a priority to not uproot the coexistence of the minor children, in cases where the addiction/detoxification does not harm the interests of the child in the long term. There are many cases where public or private programs not take care of women in therapeutic communities, outpatient programs, day centers, residential resources, etc. in which the children may be with their mothers. This situation worsens, in some cases, family breakdown and distress scenarios for the offspring; likewise, vulnerability is reinforced as a risk factor for women when they are unable to live with their children.

Also, the phenomenon of drug trafficking and consumption of substances from the feminization of poverty that affects their socio-labor and socioeducational process must be taken into account (Del Pozo, Jiménez \& Turbi, 2013). In this regard, it is important to analyze how the male partners influence in the women's contact with drugs, as well as how the initiative and abusive consumption of these lead many women to further marginalization and social exclusion (Del Pozo \& Peláez, 2013).

From this premise, we would have to consider essential to develop preventive and interventional approaches to justify the imbalance between men and women in the assumption of family responsibilities, the care of children and elders in the family, etc. directly affect the consumption of psychotropic drugs by women (Orte, 2008). It is also necessary to deconstruct the demoralizing criminalization exercised towards women-consumers, and the association of a greater psychological vulnerability, anxiety disorders, stress or depression, solely because they are women (Castaños \& Palop, 2007).

The socio-educational dimension involves the integration of drug-dependent women in the development and community participation, preventing the stigmatization of them, as well as working on improving specific and networking intervention. These objectives could be general goals to work on in the socio-educational action in prisons, that education has as one of its biggest challenges (Caride \& Gradaille, 2013).

From this standpoint, Education (prevention) focuses as a foundation all the interventions developed in drug treatment programs. From this preventive approach it would be necessary to in- 
en la mejora de la intervención específica y en red. Estos objetivos podrían ser metas generales a trabajar en la actuación socioeducativa en prisiones, que presenta la educación como uno de sus mayores retos (Caride \& Gradaille, 2013).

Desde este punto de vista, la Educación (prevención) centra como fundamento todas las intervenciones desarrolladas en los programas de tratamiento de drogas. Desde este enfoque preventivo sería necesario incorporar la Educación en todos los casos de intervención con mujeres reclusas (Adictas activas, adictas en programas de mantenimiento de metadona, ex adictas y no activas). Los programas de drogas desde la perspectiva de género, tienen un desarrollo a partir de políticas y acciones que puedan contemplar necesidades y problemáticas relacionadas con las mujeres tales como el embarazo y/o la maternidad, los problemas de abuso ejercidos hacia las chicas y su incidencia en el consumo, la situación de la prostitución femenina o el VIH (Mavrou, 2011). Deben diseñarse programas preventivos de tratamiento en los establecimientos penitenciarios que tengan en sus fundamentos preventivos la disminución de los factores de riesgo, potenciación de los factores de protección y disminución de las consecuencias negativas del consumo.

\subsection{La situación actual de las mujeres drogodependientes en prisión}

Los programas desarrollados en los centros penitenciarios españoles han sido fundamentalmente aplicados a la población masculina y sin atender a las características de feminización de la pobreza (Yagüe, 2007, 2010; Añaños, 2013). En muchos estudios de drogodependencias, que plantean los teóricos o los programas empíricos, es necesario hacer constar que no se contemplan especificidades de género, por ejemplo Orte (2008) y Llopis (2008), señalan la necesidad de incorporar la perspectiva de género en los procesos de intervención con mujeres drogodependientes, donde es pertinente temas específicos (relaciones interpersonales y de pareja, malos tratos, doble penalización social, sexualidad y relación con el cuerpo, maternidad y presencia de los hijos/as en el tratamiento, dificultades del mercado laboral, autoestima, etc.). corporate Education in all cases of intervention with women prisoners (Active Addicts, addicts in methadone maintenance programs, former addicts and non-active). Drug programs from the gender perspective have a development from policies and actions that could consider the needs and issues related to women such as pregnancy and/or maternity, abuse problems exercised towards the girls and their impact in consumption, the situation of female prostitution or HIV (Mavrou, 2011). Preventive treatment programs should be designed in penitentiary establishments that have included in their preventive foundations the decreasing of the risk factors, enhancing of the protection factors and decrease of the negative consequences of consumption.

\subsection{The actual situation of drug-dependent women in prison}

The programs developed in spanish penitentiary centers have been mainly applied to the male population and without regard to the characteristics of feminization of poverty (Yagüe, 2007, 2010; Añaños, 2013). In many studies of drug addiction that are posed by the theoretical community or the empirical programs, it is necessary to note that no gender specifics are contemplated, for example Orte (2008) and Llopis (2008) point out the need to incorporate the gender perspective in intervention processes with drug-dependent women, where it is necessary to point out specific topics (interpersonal and partner relationships, abuse, double social penalty, sexuality and relationship to the body, maternity and presence of children in treatment, difficulties in the labor market, self-esteem, etc.).

Guided by the study promoted by the Institute of Women on female ex-prisoners, $81 \%$ of them have

[ 186 ] FRANCISCO JOSÉ DEL POZO SERRANO 
Ateniendo al estudio promovido desde el Instituto de la Mujer sobre mujeres ex reclusas, el $81 \%$ de éstas han sufrido malos tratos psíquicos, el $73 \%$ han sido víctimas de malos tratos físicos y el $46 \%$ han sido víctimas de violencia sexual (Instituto de la Mujer, 2005).

Si además de haber pasado por este tipo de situaciones, le añadimos la falta de acceso a un trabajo digno, a una vivienda digna, a una seguridad económica, etc, terminando con su ingreso en prisión, nos encontramos con una mujer, con una baja o nula autoestima, una falta de desarrollo de habilidades que le faciliten ocupar su sitio en la sociedad, provocando a su vez una situación de indefensión. Esta realidad se acentúa en el caso de mujeres de etnia gitana, las cuales, no solo presentan mayores índices de haber sufrido situaciones de violencia de género, sino que muestran una escasa conciencia de la situación de violencia de la que son víctimas hecho, unido a las resistencia de su entorno, dificulta el desarrollo de programas en esta dirección.

Se debería contemplar en el diseño de los programas y en la aplicación de los mismos, aquellas necesidades específicas de género, penitenciarias, sociales, educativas, etc. sobre drogodependencias de las mujeres y madres reclusas que manifiestan las Administraciones y entidades competentes en dicha cuestión.

Podemos afirmar, tras la literatura revisada y las recomendaciones internacionales al respecto, que en España no existen programas de tratamiento socioeducativo integrales adecuados al género y al perfil de las mujeres drogodependientes (Panayotopoulos, 2008; Fernández, 2008; Añaños, 2010), mucho menos, para las penadas que se encuentran en régimen de semilibertad (módulos de mujeres y de madres, Centros de Inserción Social (CIS), unidades extrapenitenciarias, Unidades dependientes y externas, etc.). Por el contrario, se les aplican programas de tratamiento y reinserción genéricos que no tienen en cuenta sus peculiaridades como un mayor deterioro personal, familiar y social, baja autoestima, pérdida de autonomía, etc. Esto, les puede conducir al abandono de los programas en los que participan y a recaer en los consumos de drogas, en definitiva, a un significativo fracaso en su reinserción social.

A pesar de ello, en lo relativo a los programas sobre drogas en el medio penitenciario, se han desa- suffered mental abuse, $73 \%$ have been victims of physical abuse and $46 \%$ have been victims of sexual violence (Women's Institute, 2005).

If in addition to having gone through such situations, we add the lack of access to decent work, decent housing, economic security, etc., ending with their imprisonment, we find a woman with low or no self-esteem, lack of development of skills that will facilitate her to take a place in society, causing in consequence a situation of helplessness. This situation is accentuated in the case of gypsy women, which not only have higher rates of having suffered situations of gender violence, but show little awareness of the violence of which they are victims, joined with the resistance of their environment, hinder the development of programs in this direction.

Those gender-specific needs, penitentiary, social, educational, etc. on drug addiction of women and mothers who are prisoners that are manifested by the Administrations and entities on the issue should be contemplated in design of programs and in their implementation.

We can say, after the reviewed literature and international recommendations regarding the subject, that in Spain there are comprehensive socio-educational treatment programs tailored to gender and the profile of drug-dependent women (Panayotopoulos, 2008; Fernández, 2008; Añaños, 2010) much less, for those who are paying a sentence in a semiliberty regime (modules of women and mothers, Social Integration Centers (SIC), extra-penitentiary units, dependent units and external units, etc.). On the contrary, generic treatment and reintegration programs are applied to them, these programs do not take into account the peculiarities as a major personal, family and social impairment, low self-esteem, loss of autonomy, etc. This can lead to the abandonment of the programs in which they participate and relapse in the consumption of drugs, and ultimately, it can lead to a significant failure in their social reintegration.

However, in regard to drug programs in the penitentiary area, two advances have been mainly developed: One, a specific manual on drug dependency for professionals, but also for the entire population at a general level (with some concretions of application to women). Intervention on drugs in penitentiary centers, having as a priority to ensure 
rrollado fundamentalmente dos avances: Uno, un manual específico sobre drogodependencias para profesionales, aunque para toda la población a nivel general (con algunas concreciones de aplicación para mujeres). Intervención sobre drogas en centros penitenciarios con la línea prioritaria de garantizar la atención integral en los centros penitenciarios a la población interna con problemas de drogas (PNSD, 2006).

Otro, desde un avance en las desigualdades de género, el Programa de intervención en salud desde un enfoque de género con mujeres privadas de libertad-Guía práctica para la Intervención grupal con mujeres privadas de libertad (Instituto de la Mujer, 2007), etc. Aunque éste ha mejorado las estrategias técnicas al respecto, continúa manteniendo un enfoque principalmente terapéutico, y no se aplican coordinadamente por el conjunto de entidades colaboradoras y acciones que se ejecutan con las mujeres reclusas drogodependientes en segundo y tercer grado penitenciario, período en el que es fundamental prepararse para la libertad y reincorporación total (March, 2010).

\section{Metodología}

Este estudio se centra en mujeres del medio penitenciario en dos regímenes de vida (abierto y ordinario) y que se encuentran clasificadas en $2 \circ \circ 3^{\mathrm{er}}$ grado de cumplimiento de pena. La población de la que se extrajo el marco muestral fue de $3.484 \mathrm{mu}$ jeres. Se llevó a cabo un proceso estratificado llegando a muestrear aproximadamente un $17 \%$ de la población. La selección de la muestra a encuestar y entrevistar se realizó al azar entre aquellas que de forma voluntaria y previo consentimiento informado accedieron a participar, en los 42 centros seleccionados en todo el territorio nacional. La investigación es multimétodo, insertada dentro del Proyecto I+D+I denominado "Mujeres reclusas drogodependientes y su reinserción social. Estudio socioeducativo y propuestas de acción" [EDU2009-13408], con una muestra nacional en segundo y tercer grado (Administración General del Estado y Comunidad de Cataluña), correspondiente aproximadamente al 15\% de las mujeres reclusas en el panorama nacional. Se han obtenido 538 cuestionarios válidos, 61 entrevistas semi-estructuradas, a los cuales aplicaron, por un a complete care in prisons for the internal population with drug problems (PNSD, 2006).

Another one from an advance in gender inequalities, is the Health intervention program from a gender perspective with women deprived of libertyPractical guide for group intervention with women prisoners (Women's Institute, 2007), etc. Although it has improved the technical strategies, it continues to mainly maintain a therapeutic approach, and they are not applied with coordination by all the collaborating entities and actions that are executed with drug-dependent female prisoners in second and third penitentiary grade, period during which it is essential to prepare for freedom and full reinstatement (March, 2010).

\section{Method}

This study focuses on women of the penitentiary environment in two regimes of life (open and regular) and who are classified in 2nd or 3rd degree of compliance with their penalty. The population from which the sample was extracted was conformed by 3,484 women. A stratified process took place, reaching a sample of approximately $17 \%$ of the population. The selection of the sample to survey and interview was conducted at random order within those who voluntarily and with previous informed consent agreed to participate in the 42 selected centers across the country. The research is multi-method, inserted into the project I + D + I called "Drug-dependent women prisoners and their social reintegration. Socio-educational study and proposals for action" [EDU2009-13408], with a national sample in second and third grade (General Government Administration and Community of Cataluña), corresponding to about $15 \%$ of women prisoners in the national scene. 538 valid questionnaires have been obtained, 61 are semi-structured interviews to which were applied, firstly, methods

[ 188 ] FRANCISCO JOSÉ DEL POZO SERRANO

SIPS - PEDAGOGIA SOCIAL. REVISTA INTERUNIVERSITARIA [1139-1723 (2015) 26, 173-199] TERCERA ÉPOCA 
lado, métodos de análisis informáticos y programas específicos para los datos cuantitativos (SPSS, V. 15 y 20) y métodos de análisis de contenido para los datos cualitativos. El análisis se ha realizado antes y durante el internamiento, a partir de cuatro perfiles de mujeres reclusas ( $A A$ : adictas activas ( $\left.8^{\prime} 20 \%\right)$, EX: ex adictas (EX: $67^{\prime} 21 \%$ ), NA: no adictas (NA: 14,75\%) y $\operatorname{PMM}(9,84 \%)$ : adictas en programas de mantenimiento de metadona).

\section{Resultados y Discusión}

Como hemos planteado en el marco teórico y estado de la cuestión del estudio, la investigación, centra procesos de recuperación de las adicciones (desintoxicación y/o deshabituación) en relación a los programas de tratamiento y aquellos factores que identificamos de riesgo como de protección vinculados a la reinserción. Abordemos por tanto, aquellos resultados más significativos.

\subsection{Factores de riesgo}

3.1.1. Ausencia de programas específicos, motivaciones para el tratamiento y prevención de recaídas.

Para comenzar, es conveniente señalar, que el 57\% de las mujeres; por tanto algo más de la mitad, piensan que los programas de tratamiento favorecen más a los hombres más que a las mujeres. Este problema de rostro femenino, evidencia las históricas discriminaciones de género sufridas por las reclusas como minoría penitenciaria (Almeda, 2003; Igareda, 2006; Del Pozo, 2012). Avanzando en las relaciones existentes entre los diversos perfiles de consumo y el tratamiento penitenciario se explicita que el $67,21 \%$ de la población de mujeres son ex adictas, un 9,84\% están en programa de mantenimiento de metadona y un $8,20 \%$ son adictas activas. El resto, son no adictas (Figura no1). Desde la investigación, quizás el factor de riesgo más problemático se sitúa en que el $62,3 \%$ de las mujeres, nunca ha recibido tratamiento (Figura no2). Este dato es impactante, puesto que los programas de prevención de recaídas deberían ser el principal enfoque de los programas para las mujeres, ya que la mayoría están en el perfil de ex consumidoras. of computer analysis and specific programs for quantitative data (SPSS, V. 15 and 20) and methods of content analysis for the qualitative data. The analysis was performed before and during the internment, starting from four profiles of women prisoners (AA: Active addicts (8'20\%), EX: ex addicted (EX: 67'21\%), NA: not addicted (NA : 14.75\%) and PMM (9.84\%) addicts in methadone maintenance programs).

\section{Results and Discussion}

As we stated in the theoretical framework and the state of the question of study, the research focused recovery processes of addiction (detoxification/rehabilitation) in relation to treatment programs and those factors that we identified as risky as well as protection related to reintegration. Let us therefore approach the most significant results.

\subsection{Risk factors}

3.1.1. Absence of specific programs, motivation for treatment and relapse prevention.

To begin, it should be noted that $57 \%$ of women; therefore more than half of them, think that treatment programs favor men more than women. This problem with a female face evidences the historical gender discrimination suffered by women prisoners as prison minority (Almeda, 2003; Igareda, 2006; Del Pozo, 2012). Advancing in the existent relationships between the various consumption profiles and prison treatment it is made clear that $67.21 \%$ of the female population are former addicts, $9.84 \%$ are in methadone maintenance program and $8.20 \%$ are active addicts. The rest are not addicted (Figure no1). From the research, perhaps the most problematic risk factor lies in that $62.3 \%$ of women have never received treatment (Figure n०2). This finding is striking, since the relapse prevention programs should be the main focus of programs for women, since most fall into the profile of ex-consumers. 
Figura 1. Perfil de consumo de las reclusas

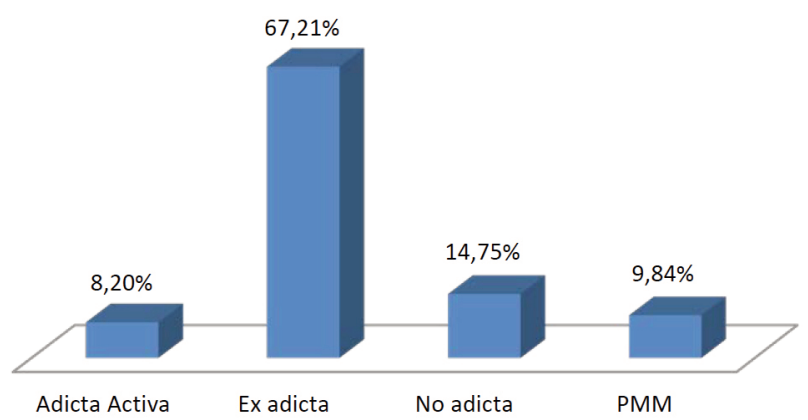

Fuente: Elaboración propia a partir de los cuestionarios a las mujeres.

Figura 2. Tratamiento para dejar o controlar el consumo de drogas

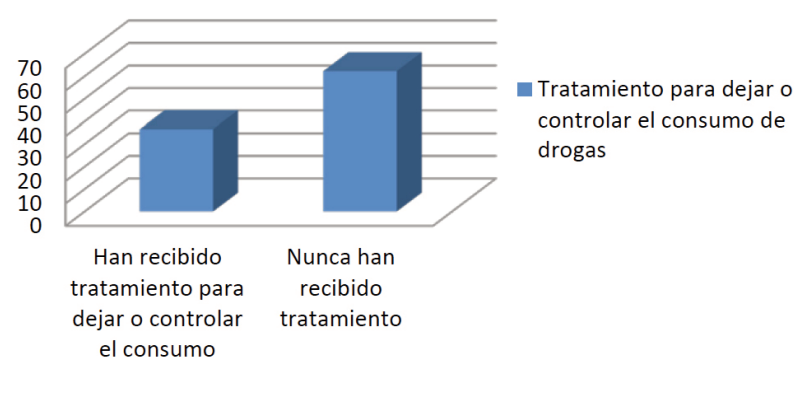

Fuente: Elaboración propia a partir de los cuestionarios a las mujeres.

Conociendo que una gran parte de la población ha sido ex consumidora, y otra parte se encuentra con programas de metadona o son consumidoras activas, debemos reflexionar sobre esta situación de alto riesgo. Igualmente de las entrevistas se pudo extraer que 40 mujeres eran ex adictas (EX: 67,21\%). Sin embargo, según los datos, 77 mujeres no siguieron el tratamiento que estaban recibiendo antes del cumplimiento de su pena. Es posible deducir que no lo siguieron porque no querían, porque no se les ofreció o porque no había oferta de este programa en el centro penitenciario. Esta situación es preocupante, uno de los principales factores de riesgo para la recaída que ha detectado el estudio.

Esta realidad se problematiza profundamente, al analizar algunos de los inconvenientes que expresan las mujeres para la realización de programas derivados del propio sistema penitenciario (dificultades por estar en otras actividades: O'7\%; desconfianza a las normas o programas: $0,9 \%$; carencia de programas $\mathrm{u}$ ofrecimiento por conducción o traslado:
Figure 1. Consumption profile of the women prisoners

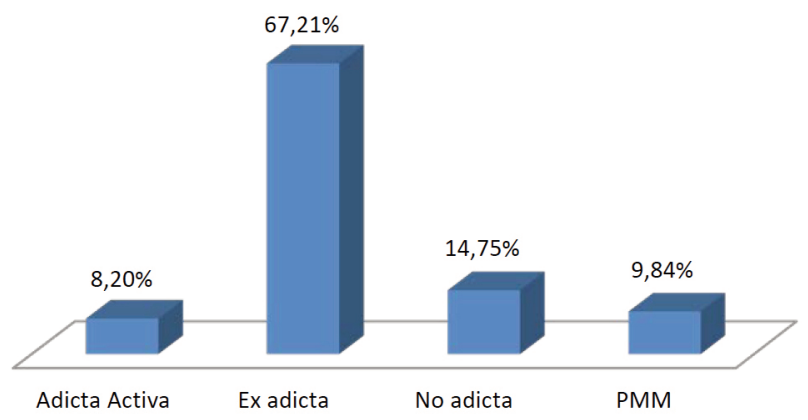

Source: Compiled from the questionnaires applied to women.

Figure 2. Treatment for stopping or controlling drug

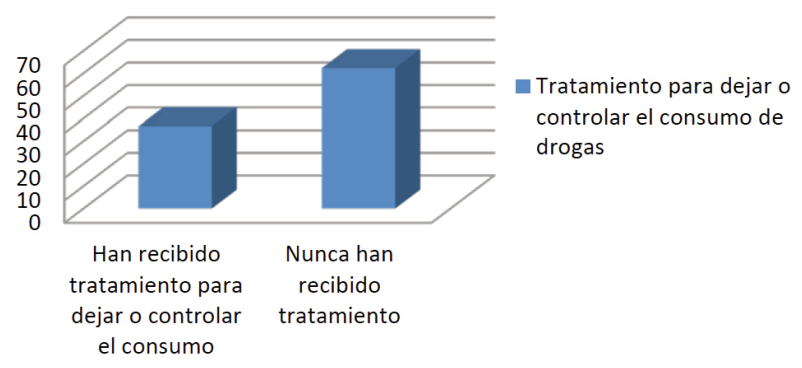

Source: Compiled from the questionnaires applied to women.

Knowing that a large part of the population are ex-consumers, and the other part are on methadone programs or are active consumers, we must reflect on this high risk situation. Equally, from interviews it could be extracted that 40 women were ex-addicts (EX: 67.21\%). However, according to the data, 77 women did not follow the treatment they were receiving before completion of their sentence. It is possible to deduce that they did not follow it because they did not want to, because they were not offered the treatment, or because there was no offer this program in the penitentiary center. This situation is worrying, and it is one of the major risk factors for relapse that the study has detected.

This reality is deeply problematized when analyzing some of the inconveniences that women express for the realization of programs derived under the prison system (difficulties for being on other activities: $0.7 \%$; distrust of rules or of the programs: $0.9 \%$ lack of programs or offers for transfer or conduction $0.4 \%)$. This how an ex-addict expresses the

[ 190 ] FRANCISCO JOSÉ DEL POZO SERRANO 
$0,4 \%)$. Así expresa una de las ex adictas la ineficacia y desconfianza hacia los programas "A mí no me sirve de nada" (EX_E2O9).

Las mujeres ex adictas otorgan como principales motivos que no lo necesitan porque ya no consumen. Pero es en el caso de las adictas activas donde encontramos el mayor campo de acción. El altísimo porcentaje de un 52,2\% piensa que no necesitan un programa. Esta realidad, sitúa el tratamiento con esta población como un gran reto. También exponen las que se encuentran en PMM, aunque con un bajo porcentaje, que no le ofrecieron entrar en los mismos (1,6\%); y otras aun estando en los mismos que no lo necesitan $(3,1 \%)$ o que no consumen ( $1,6 \%$ ); lo que evidencia la necesidad de fortalecer los programas de prevención de recaídas. La dificultad en autoconfianza, el afrontamiento del período en semilibertad, el bajo nivel de desintoxicación, etc. pueden producir situaciones de probemáticas y constituyen un riesgo evidente que necesita un apoyo tratamental a las mujeres en PMM. Atendamos en un fragmento de las entrevistas:

\footnotetext{
“Aquí no, tengo mucho miedo aquí, eh. Paso, paso, me ha machacado la vida pero no he consumido. Tuve una recaída pero ya no. Me lo han ofrecido pero no (Eso fue aquí en la cárcel, le ofrecieron heroína y cocaína). (MM_E109).
}

Sin embargo, los principales problemas que establece el personal profesional para conseguir los objetivos presentes en los programas relacionados con el ámbito de las drogodependencias, a partir de los datos cualitativos (Pregunta no 48), serían por orden de prioridad en primer lugar, problemas fundamentalmente de tipo personal: Poca motivación, enfermedad mental, no asunción del problema de la dependencia, cuadro tóxico por ingesta de sustancias.

\subsection{Factores de protección}

Desde el estudio diferenciado por perfiles de consumo encontramos como los motivos expuestos más significativos por cada tipo poblacional que motivaron el comienzo del tratamiento. inefficiency and mistrust towards the programs "It is of no use to me" (EX_E209).

The ex-addicted women propose as main motives that they do not need it because they no longer consume. But it is in the case of active-addicts where we find the bigger action field. The very high percentage of $52.2 \%$ think they do not need a program. This fact places the treatment with this population as a challenge. The ones that are in MMP also expose, but with a low percentage, that they were not offered to enter in them (1.6\%); and others even being in them, said they do not need it (3.1\%) or that they do not consume (1.6\%); which demonstrates the need to strengthen programs for relapse prevention. The difficulty in self-confidence, coping with the semi-freedom period, the low level of detoxification, etc. can produce problematic situations and constitute a clear risk that requires a treatment support for women in MMP. Let's address a fragment of the interviews:

"Not here, I am really scared here, eh. I pass, I pass, it has crushed my life but I haven't consumed. I had a relapse but not anymore. It has been offered to me but no. (That was here in the prison, where she was offered heroin and cocaine). (MM_E109).

Nevertheless, the main problems that the professional staff establishes to achieve the objectives present in the programs related to the field of drug dependency, from qualitative data (Question n०48), and by priority order would be, in the first place, problems of personal kind mainly: Low motivation, mental illness, no assumption of the dependency problem, toxicity by ingestion of substances.

\subsection{Protection factors}

From the study differentiated by consumption profiles, we found as the reasons given as most significant for each population type that led to the start of treatment. 
Mientras que las adictas activas presentan las presiones familiares como un factor protector poco importante en su recuperación (13\%), según se va produciendo un proceso de recuperación de desintoxicación/deshabituación en las mujeres, éstas, van asumiendo desde estados de mayor contemplación sobre la problemática (Prochaska \& Diclemente, 1982); donde la familia (madre, padre, hermanos/as y pareja, etc.), es sustancial para la acción en la transformación y el mantenimiento de la abstinencia. Así, las mujeres en programas de metadona le dan un valor del 32,8\%, que se encuentran en una fase más profunda de intento y tratamiento de control del consumo que las adictas activas.

En este sentido, las mujeres ex adictas, son las que más lo valoran desde una perspectiva longitudinal del proceso de adicción y desintoxicación/deshabituación, haciendo constar en un 92,8\% que la familia es el factor principal para la protección en la reducción y eliminación del consumo (tal y como se ha fundamentado en el marco teórico). Así expresa una de ellas en una entrevista la importancia de los hermanos en su vida y su proceso recuperador, cuando se le pregunta por el mantenimiento de la abstinencia:

"para ayudar a mi madre, entonces no le puedo fallar, porque como me hagan doping, no, no le puedo fallar a mi hermano, no le puedo fallar" (EX_E316).

3.2.1. Factores de protección individuales: Embarazo, salud y otros

Los factores individuales relacionados con los procesos de contemplación y acción del problema del consumo, también son importantes. Un número relevante de mujeres (98) que siguieron su tratamiento en prisión, lo hicieron porque lo necesitaban:

\footnotetext{
"Más que el programa nosotros tenemos que concienciarnos y poner mucho de nuestra parte, mucha voluntad, pero ahí te dan unas charla que te brindan su apoyo" (EX_E310). Así de rotundamente expresa una mujer ex adicta la necesidad de tomar las riendas de la propia vida para asumir con plena consciencia la voluntad para el necesario cambio:
}

The family as a protection factor

While the active addicts have family pressures as an little important protective factor in their recovery $(13 \%)$, as a process of recovery detox/cessation in women is developed, they are taking an assumption from higher states of contemplation over the problematic (Prochaska \& Diclemente, 1982); where the family (mother, father, brothers/sisters and partners, etc.), is substantial for action in the transformation and maintenance of abstinence. Thus, women in methadone programs give it a value of $32.8 \%$, which are in a deeper phase of attempt and treatment for control of the consumption than the active addicts.

In this sense, the ex addicted women are those that value the most from a longitudinal perspective of the process of addiction and detox/cessation, stating in a $92.8 \%$ that the family is the main factor for the protection in reduction and elimination of the consumption (just as it has been proved on the theoretical framework). This is how one of them expressed in an interview the importance of siblings in her life and her recovery process, when she is asked about maintaining abstinence:

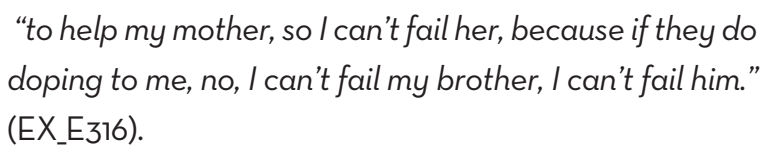
doping to me, no, I can't fail my brother, I can't fail him." (EX_E316).

3.2.1. Individual protection factors: Pregnancy, health and others

Individual factors related to the processes of contemplation and action of the problem of consumption are also important. A significant number of women (98) who followed their treatment in prison, did so because they needed it:

\footnotetext{
"More than the program we have to be conscious and put a lot of effort on it, a lot of will, but there they give you some talks that support you." (EX_E310). That's how strongly an ex-addicted woman expresses the need to take charge of her own life to take assume with full consciousness the will for the necessary change:
}

[ 192 ] FRANCISCO JOSÉ DEL POZO SERRANO 
"Te tienes que levantar tú por ti misma. Yo no puedo decir a nadie que me levante si luego yo no [...] tengo que ser yo" (EX_E2O4).

Respecto al embarazo, mientras que las mujeres adictas no dan significatividad a esta causa $(1,4 \%)$, son las que se encuentran en programas de mantenimiento de metadona (que por lo general, ya han pasado de un estado contemplativo a la acción), las que otorgan mayor relevancia a esta motivación con un $7,8 \%$. Aunque sigue siendo un porcentaje muy bajo.

$\mathrm{Si}$ analizamos los factores de protección individuales referidos a la conciencia de recuperación a partir de la enfermedad física (VIH, hepatitis, otras) y enfermedad mental, se evidencia que las mujeres en programas de metadona, presentan en un $14.1 \%$ el valor otorgado a este motivo. Estas mujeres, que se encontrarían en un estado de acción respecto a su adicción, presentan una situación de conciencia más profunda que las adictas activas que prácticamente no señalan este motivo $(1,4 \%)$ como factor de protección. También, encontramos que las mujeres en PMM, participan de un estadio más maduro y consciente en el proceso de recuperación que las adictas. Es este caso, es la salud física la que tiene una mayor presencia, superando a la enfermedad mental que queda representada en un $10,9 \%$. Sin embargo las mujeres adictas activas, sí otorgan importancia a los problemas psíquicos en un 10,9\%.

Sin embargo, el personal profesional advierte factores personales como es la maternidad, el embarazo - la estabilidad personal, para ayudar a la mujer a tomar decisiones de cambio de estilo de vida, especialmente si la mujer tiene o va a tener hijos/as. Así expresa una de las mujeres la motivación en los procesos de recuperación de las madres por razón de maternidad:

"Yo sé que para las madres que tienen hijos es una gran motivación pero claro tú también tienes que demostrar que quieres cambiar" (EX_E107).

Más de la mitad del personal (65,2\%), por tanto, cree en los resultados satisfactorios por parte de las mujeres en relación a la consecución de objetivos, lo que indica que si hubiera programas suficientes para toda la población y adecuados a las características, podrían reducirse las situaciones problemáticas.
"You have to get up by yourself. I can't tell anyone to pick me up I don't do it [...] it has to be me" (EX_E2O4).

Regarding pregnancy, while addicted women do not give significance to this cause $(1.4 \%)$ the ones found in methadone maintenance programs (which usually have passed from contemplative state to the action), are the ones that give greater prominence to this motivation with a $7.8 \%$. Although it is still a very low percentage.

If we analyze the individual protection factors related to awareness of recovery from a physical illness (HIV, hepatitis, etc.) and mental illness, it is evident that women in methadone programs present by $14.1 \%$ the awarded value to this motive. These women, who would be in a state of action on matters of their addiction, have a deeper state of consciousness that active addicts who practically don't point to this motive $(1.4 \%)$ as a protective factor. Also, we found that women in MMP, participate in a more mature and conscious stage in the recovery process that the ones who are addicted. In this case, it is the physical health that has a greater presence, overcoming mental illness that is represented by $10.9 \%$. However, the women who are active-addicts do award importance to psychological problems on a $10.9 \%$.

However, the professional staff warns of personal factors such as maternity, pregnancy or personal stability, to help women on making decisions for change in lifestyle, especially if the woman has or will have children. This is how one of the women expressed motivation in the recovery processes of mothers for reasons of maternity:

"I know that for the mothers who have children it is a great motivation, but of course you have to show that you want to change" (EX_E107).

More than half of the staff (65.2\%), therefore, believes in the successful results by women in relation to the achievement of objectives, indicating that if there were enough programs for the entire population and they were adapted to the characteristics, problematic situations could be reduced. 


\section{Principales conclusiones}

Si se tienen en cuenta las más relevantes conclusiones en relación a los factores de riesgo y protección atendidos en los programas y la adecuación a las características de las mujeres ante sus procesos de reinserción se destaca:

\subsection{Factores de riesgo}

- Discriminación de género: Se percibe por parte de las mujeres que se favorece en los programas más a hombres reclusos que a las mujeres.

- Prevención de recaídas: Prácticamente el 70\% de las mujeres son ex consumidoras, y sin embargo no se contempla un enfoque necesario en la prevención de recaídas ya que no tienen tratamiento en prisión el 62,3\% de las mismas. Las mujeres ex adictas otorgan como principales motivos que no lo necesitan porque ya no consumen. Pero es en el caso de las adictas activas donde encontramos el mayor campo de acción. El altísimo porcentaje de un 52,2\% piensa que no necesitan un programa.

- Acceso y eficacia de los programas: Existe un grupo de mujeres que plantean su desconfianza en los programas, desinformación de los mismos o compatibilidad con otras actividades $(22$ mujeres manifiestan su desconfianza hacia las normas y/o efectividad de los programas de tratamiento). Sin embargo, el personal profesional advierte que son otros los problemas que interfieren en el logro de los objetivos marcados por los programas y que tienen que ver con problemas personales de las mujeres, tales como la inconstancia, la enfermedad mental y esfuerzo o la reticencia al cambio.

\subsection{Factores de protección}

- La familia: Las mujeres ex adictas, son las que valoran desde los diversos perfiles $92,8 \%$ que la familia supone la motivación principal en su proceso de recuperación.

- La salud y los factores individuales: Las ex adictas contemplan que los factores individuales son muy importantes para dejar el consumo. Respecto a lo relacionado con la salud como

\section{Main conclusions}

Taking into account the most relevant conclusions regarding the risk factors and protection addressed in the programs, and the adaptation to the characteristics of women on their reintegration processes:

\subsection{Risk Factors}

- Gender discrimination: It is perceived by women that programs favor male prisoners more than women prisoners.

- Relapse prevention: Almost 70\% of women are ex-consumers, yet a necessary approach is not contemplated in preventing relapse because $62.3 \%$ of them do not have a treatment in prison. Ex-addicted women granted as main reasons that they do not need it because they no longer consume it. But it is in the case of activeaddicts where we find the largest field of action. The high percentage of $52.2 \%$ think they do not need a program.

- Access efficiency of the programs: There is a group of women who point out their distrust in the programs, misinformation of them or compatibility with other activities (22 women expressed their distrust of rules and/or effectiveness of the treatment programs). However, professional staff notes that there it is other problems that interfere with the achievement of the objectives set by the programs and that they deal with personal problems of the women, such as inconsistency, mental illness and effort or reluctance to change.

\subsection{Protection factors}

- Family: Ex-addicted women are those that value from the various profiles $92.8 \%$ that the family is the main motivation in their recovery process.

- The health and individual factors: The former addicts contemplate that individual factors are very important to stop the consumption. Regarding the related to health as the main moti-

[ 194 ] FRANCISCO JOSÉ DEL POZO SERRANO 
motivación principal, son las que PMM, quienes valoran esa situación como principal para el mantenimiento y la recuperación.

- Percepción positiva del personal profesional en la consecución de objetivos. El 65,2\% del personal profesional piensa que los resultados de las mujeres son satisfactorios. Este dato evidencia cruzado con la poca participación principalmente de las mujeres ex adictas en los programas, que es necesaria la implementación de mayores programas, universalidad de acceso e inclusión de las características específicas de género.

\section{Propuestas}

Tras el estudio, se propone el PROSO-MD que hace referencia al Programa Socioeducativo, dentro del MSE (Del Pozo \& Añaños, 2013), en la tipología de "Mujeres Drogodependientes".

Se concibe dentro de un itinerario de inserción/reinserción, de acuerdo al proceso penal/ penitenciario de las mujeres. Diseñado en cinco fases en proceso de privación de libertad-cumplimiento de condena, se estructura en un proceso progresivo de actuaciones desarrollado a través de la situación preventiva sin condena, primer grado penitenciario, segundo grado, tercer grado y libertad condicional.

A partir de los fundamentos y diagnóstico estudiado en el desarrollo del estudio, hemos priorizado un conjunto de necesidades y potencialidades sobre las que actuar, desarrollando aquellos contenidos y estrategias que hemos creído más pertinentes y adecuados a las características encontradas.

En ese sentido, es necesario destacar que el proceso se concibe a partir de siete áreas de acción generales que hemos priorizado como más importantes: Familia, infancia, sociocultural, socioeducativo, socio- laboral, salud y género.

La estructura del programa contempla seis apartados: Áreas de acción, objetivos generales, contenidos- acciones, metodologías, temporalización y evaluación. En relación con la salud, se basa fundamentalmente en promoción de la salud y en la acción socioeducativa en la drogodependencia. Para ello, es imprescindible, en el marco de la intervención que exista una multidiciplinariedad médico-psicológica en el tratamiento de adicciones, pero en nuestro vation, MMP are those who value this situation as principal for the maintenance and recovery. - Positive perception of professional staff in achieving the objectives: $65.2 \%$ of the professional staff feel that the results of women are satisfactory. This data points out along with the low participation of mainly the women in the ex-addicted programs, that the the implementation of major programs is necessary, as well as universal access and inclusion of specific gender characteristics.

\section{Proposals}

After the study, the PROSO-MD referring to Socioeducational Program within the MSE (Del Pozo \& Añaños, 2013), in the category of "Drug-dependent Women" is proposed.

It is conceived within a pathway of insertion/reinsertion, according to the criminal/penal process for women. Conceived in five phases in the process of liberty deprivation-compliance of penalty, is structured in a progressive process of actions developed through the preventive situation without conviction, prison first penitentiary grade, second grade, third grade and probation.

From the bases and diagnostic studied in the development of the study, we have prioritized a set of needs and potentials on which to act, developing those contents and strategies that we have considered to be more relevant and appropriate to the characteristics found.

In this regard, it should be noted that the process is conceived from seven general areas of action that we have prioritized as most important: Family, childhood, socio-cultural, socio-educational, socio-labor, health and gender.

The program structure includes seven sections: Areas of action, general objectives, contents-actions, methods, timing and evaluation. In relation to health, it is mainly based on promoting health and socio-educational action on the drug dependency. For this, it is essential, in the context of the intervention to exist a medical-psychological multidisciplinarity in the treatment of addictions, but in our case, we have only inclu- 
caso, hemos incluido en el programa únicamente las principales dimensiones socioeducativas.

A modo de ejemplo y teniendo en cuenta el caso de las ex adictas como una población de especial riesgo por la carencia de programas en la prevención de recaídas, exponemos la siguiente tabla-resumen no2. ded in the program the major socio-educational dimensions.

By means of an example and considering the case of former addicts as a population at particular risk for lack of programs in preventing relapses, we present the following summary-table no.2.

\section{Tabla 2. PROSO MD- EX ADICTAS}

\begin{tabular}{|c|c|c|c|c|c|c|}
\hline $\begin{array}{l}\text { Grado peni- } \\
\text { tenciario en } \\
\text { el Itinerario } \\
\text { de inserción }\end{array}$ & $\begin{array}{l}\text { Áreas } \\
\text { de acción }\end{array}$ & $\begin{array}{l}\text { Objetivos } \\
\text { generales }\end{array}$ & $\begin{array}{l}\text { Contenidos- } \\
\text { Acciones }\end{array}$ & Metodologías & Temporalización & Evaluación \\
\hline $\begin{array}{l}\text { Tercer } \\
\text { grado EX } \\
\text { ADICTAS }\end{array}$ & $\begin{array}{l}\text { EDUCA- } \\
\text { CIÓN } \\
\text { PARA LA } \\
\text { SALUD Y } \\
\text { DROGAS }\end{array}$ & $\begin{array}{l}\text { Participar en } \\
\text { un programa } \\
\text { selectivo de } \\
\text { cambio en el } \\
\text { que se en- } \\
\text { cuentra. }\end{array}$ & $\begin{array}{l}\text { Identificación de } \\
\text { situaciones de } \\
\text { riesgo.Identifica- } \\
\text { ción de potencia- } \\
\text { les.Prevención de } \\
\text { recaídas: Entrena- } \\
\text { miento de habili- } \\
\text { dades de afronta- } \\
\text { miento. Reestructu } \\
\text { ración cognitiva y } \\
\text { reequilibrio del } \\
\text { estilo de vida }\end{array}$ & $\begin{array}{l}\text { Enfrenta- } \\
\text { miento de se- } \\
\text { ñales de reca- } \\
\text { ída y } \\
\text { derivación a } \\
\text { los servicios } \\
\text { ambulatorios } \\
\text { del contexto. }\end{array}$ & $\begin{array}{l}1 \text { sesión con fa- } \\
\text { milias o redes } \\
\text { externas para } \\
\text { formación en } \\
\text { prevención de } \\
\text { recaídas. }\end{array}$ & $\begin{array}{l}\text { Grado de } \\
\text { participación } \\
\text { de las redes } \\
\text { externas y la } \\
\text { familias.Dura- } \\
\text { ción de la } \\
\text { abstinencia }\end{array}$ \\
\hline
\end{tabular}

Fuente: Elaboración propia

Table 2. PROSO MD- EX ADICTAS

\begin{tabular}{|l|l|l|l|l|l|l|}
\hline $\begin{array}{l}\text { Penitentiary } \\
\text { grade in the } \\
\text { insertion } \\
\text { itinerary }\end{array}$ & $\begin{array}{l}\text { Areas of ac- } \\
\text { tion }\end{array}$ & $\begin{array}{l}\text { General } \\
\text { objectives }\end{array}$ & Contents-actions & Methodologies & Timing & Evaluation \\
\hline $\begin{array}{l}\text { Third } \\
\text { Erade }\end{array}$ & $\begin{array}{l}\text { Education } \\
\text { for health } \\
\text { and drugs }\end{array}$ & $\begin{array}{l}\text { To participate } \\
\text { in a selective } \\
\text { program of } \\
\text { change that } \\
\text { they are in. }\end{array}$ & $\begin{array}{l}\text { ldentification of } \\
\text { risk situations. } \\
\text { ldentification of } \\
\text { potentials } \\
\text { Prevention of re- } \\
\text { lapses: Training in } \\
\text { coping skills. } \\
\text { Cognitive restruc- } \\
\text { turing and reba- } \\
\text { lancing lifestyle. }\end{array}$ & $\begin{array}{l}\text { Dealing with } \\
\text { relapse sig- } \\
\text { nals and refe- } \\
\text { rral to outpa- } \\
\text { tient services } \\
\text { in the context. }\end{array}$ & $\begin{array}{l}\text { 1 session with } \\
\text { families or ex- } \\
\text { ternal networks } \\
\text { folapse preven- } \\
\text { tion. }\end{array}$ & $\begin{array}{l}\text { Grade of } \\
\text { participation } \\
\text { of the exter- } \\
\text { nal networks } \\
\text { and the fami- } \\
\text { lies. } \\
\text { Duration of } \\
\text { the absti- } \\
\text { nence. }\end{array}$ \\
\hline
\end{tabular}

Source: Self elaboration.

[ 196 ] FRANCISCO JOSÉ DEL POZO SERRANO 


\section{Bibliografía / References}

Almeda, E. (2003). Mujeres Encarceladas. Barcelona: Ariel.

Añaños, F. (2010). Mujeres presas y su relación con las drogas. Implicaciones desde la Educación Social. En Fanny T. Añaños (Coord.), La Educación Social en contextos de riesgo y conflicto: Las Mujeres en las prisiones. (págs. 77-100). Barcelona: Gedisa,

-(2013). Formación educativa previa ante las discriminaciones: las mujeres reclusas en España. Revista de Educación, 360, 91-118.

Ayala, N., \& Fornaguera, A. (1996). Prevención integral: Enfoques crítico y ecológico. Ciencias Sociales, 73-74, 125-131.

Caride, J.A., \& Gradaílle, R. (2013). Educar en las cárceles: nuevos desafíos para la educación social en las instituciones penitenciarias. Revista de Educación, 360. 36-47.

Castaños, M., \& Palop, M. (2007). El proceso de intervención en mujeres con drogodependencia: Pautas para incluir la perspectiva de género. En Mónica Castaños, Carmen Meneses, Mercedes Palop, Mercedes Rodríguez, Silvia Tubert, Intervención en drogodependencias con enfoque de género. (págs. 60-75). Madrid: Instituto de la Mujer.

Del Pozo, F. J. (2012). Acción Socioeducativa en el Medio Penitenciario con mujeres y madres reclusas: Realidades y desafíos desde un enfoque de Género. En Emilio López (dir.). Mujeres y educación social: Teoría y praxis para la intervención socio-educativa. Madrid: UNED

-(2013). Educación social para la salud: proyección, acción y profesionalización. Revista Médica de Risaralda, Abril, 19, (1), 75-80.

Del Pozo, F.J., \& Gil, F. (2012). Profesionalización educativa de la Reinserción en los Centros Penitenciarios. En Sonia Morales, Juan Lirio y Rosa Marí, La Pedagogía Social en la Universidad. Investigación, formación y compromiso social. (págs. 285-299). Valencia: Nau Llibres,

Del Pozo, F. J., \& Añaños T. F. (2013). La Educación Social Penitenciaria ¿De dónde venimos? Y ¿̇hacia dónde vamos? Revista Complutense de Educación, 24 (1), 47-68.

Del Pozo, F. J., \& Peláez, C. (2013). La educación para la igualdad: una necesidad académica y profesional para la acción socioeducativa. En Magdalena Jiménez y Francisco José del Pozo (Coord.), Propuestas didácticas de Educación para la lgualdad. (págs. 245-272). Granada: Editorial Natívola,

Del Pozo, F. J., Jiménez, F., \& Turbi, Á M. (2013). Los programas de tratamiento: Actuación socioeducativa y sociolaboral en prisiones, Pedagogía Social. Revista Interuniversitaria, (22), 55-72.

Del Pozo, F. J., Añaños, F., \& García, M. (2013). El tercer sector y las entidades no penitenciarias en los procesos de reinserción: El tratamiento penitenciario desde las mujeres reclusas y el personal profesional. En Susana Torío, Omar García-Pérez, José Vivente Peña y Carmen Ma Fernández (Coords.), La crisis social y el Estado del bienestar: las respuestas de la Pedagogía Social. (pp.428-435).Gijón: Universidad de Oviedo.

FAD (Fundación de Ayuda a la adicción). (2013). Tratamiento. Retrieved from http://www.fad.es/contenido.jsp?id_nodo=77

Fernández, A (2008). Análisis comparativo entre hombres y mujeres en prisión: situación coyuntural y relaciones familiares. En Fanny T. Añaños, Francisco José del Pozo e losifina Mavrou (Coords.), Educación Social en el Ámbito Penitenciario: Mujeres, Infancia y Familia (págs. 32-48) Granada: Natívola,

IIPP (2010). Informe general 2010. Madrid: Ministerio del Interior. Retrieved from http://www.institucionpenitenciaria.es/web/export/sites/default/datos/descargables/publicaciones/Informe_General_2010_acc.pdf

IIPP (2012). Portal Programas de salud. Intervención con drogodependientes. Retrieved from http://www.institucionpenitenciaria.es/web/portal/laVidaEnPrision/atencionSanitaria/programasSalud.html

IIPP (2013). Reeducación y Reinserción. Retrieved from de http://www.institucionpenitenciaria.es/web/portal/Reeducacion

IIPP (2014). Fondo documental. Circulares e instrucciones. Retrieved from http://www.institucionpenitenciaria.es/web/portal/documentos/instrucciones/

PREVENCIÓN Y TRATAMIENTO EN EL ÁMBITO PENITENCIARIO: LAS MUJERES RECLUSAS DROGODEPENDIENTES EN ESPAÑA [ 197 ] SIPS - PEDAGOGIA SOCIAL. REVISTA INTERUNIVERSITARIA [1139-1723 (2015) 26, 173-199] TERCERA ÉPOCA 
Igareda, N. (2006). Mujeres, integración y prisión. Boletín Criminológico. Instituto andaluz interuniversitario de criminología, 86, 1-4.

Instituto de la Mujer (2005). Realidad social de las mujeres in techo, prostitutas, ex reclusas y drogodependientes de España. Madrid: Instituto de la Mujer.

Instituto de la Mujer (2007). Guía práctica para la intervención grupal con mujeres. Madrid: Instituto de la Mujer.

Lipton, D. S; Gregory, F. P., \& Wexler, H. K. (2000). Effectiveness of Treatment-Based Drug Courts in Reducing Criminal Recidivism. Criminal Justice and Behavior, 27, 72-96.

Llopis, J.J. (2008). Estudio sobre las perspectivas de mejora de la asistencia a las mujeres drogodependientes con hijos en Europa. Implicaciones y consecuencias. En Fanny T. Añaños, Francisco José Del Pozo e losifina Mavrou (Coords.), Educación Social en el Ámbito Penitenciario: Mujeres, Infancia y Familia. (págs. 261-270). Granada: Natívola.

March, M. (2010). Criterios y elementos educativos y metodológicos en los programas de prevención de drogodependencias. En Francisco José Del Pozo, Fanny T. Añaños, losifina Mavrou y Diego Sevilla (Coords.), Educación, Salud y Drogodependencias: Enfoques, programas y experiencias en ámbitos de exclusión. (págs. 195-216.) Madrid: Drugfarma.

Mavrou, I. (2011). El fenómeno de las drogodependencias desde enfoques de género: Una aproximación a la Europa mediterránea En Magdalena Jiménez, Victoria Robles, Fanny T. Añaños y Francisco José Del Pozo (Coords.), Educación para la lgualdad: Reflexiones y Propuestas. (págs. 103-116). Granada: Natívola

NIDA. National Institute on Drug Abuse (2012). El abuso de drogas y la drogadicción. Accesible en http://www.drugabuse.gov/es/temas-relacionados/el-abuso-de-drogas-y-la-drogadiccion.

OMS (2012). Temas de salud. Recuperado de: http://www.who.int/topics/es/index.html

Orte, C., Ballester, L., \& March, M. (2013). El enfoque de la competencia familiar, una experiencia de trabajo socioeducativo con familias. Pedagogía Social. Revista Interuniversitaria, 21, 13-37

Prochaska, J. O., \& DiClemente C. C. (1982). Transtheoretical therapy: Toward a more integrative model of change. Psychotherapy: Theory, Research and Practice, 19 (3), 276-288.

Pantoja, L., \& Añaños, F. T. (2010). Actuaciones socioeducativas con menores vulnerables, en riesgo, relacionados con las drogas. Reflexiones críticas. Pedagogía Social. Revista Interuniversitaria, 17, 109-122.

Panayotopoulos, M. (2010). Perspectivas penitenciarias europeas. Informe sobre las mujeres y los niños en las prisiones. En Fanny T. Añaños (coord.), Las mujeres en las prisiones. La educación Social en contextos de riesgo y conflicto. (págs. 157-164). Barcelona: Gedisa.

PNSD (2006). Actuar es posible. Intervención sobre drogas en el Medio Penitenciario. Madrid: Ministerio de Sanidad y Consumo-Delegación del Gobierno para el Plan Nacional sobre Drogas. Recuperado de: http://www.pnsd.msc.es/Categoria2/publica/pdf/IntervCCPP.pdf

SOCIDROGALCOHOL (2012). Documento de Consenso en prevención de la Drogodependencia. Socidrogalcohol. Recuperado de: http://www.prevencionbasadaenlaevidencia.net/uploads/PDF/Doc_Consenso_Prevencion.pdf

Urbano, A. y Arostegui, E. (2004). La mujer drogodependiente: Especificidades de género y factores asociados. Bilbao: Instituto Deusto de Drogodependencias-Universidad de Deusto.

Yagüe, C. (2007). Mujeres en prisión. Intervención basada en sus características, necesidades y demandas. REIC. Revista española de investigación criminológica, 5, 1-24.

Yagüe, C. (2010). Panorama actual de la situación de las mujeres y madres en los centros penitenciarios españoles. El programa de igualdad. En Fanny T. Añaños (coord.), Las mujeres en las prisiones. La educación Social en contextos de riesgo y conflicto. (págs.183-200). Barcelona: Gedisa.

[ 198 ] FRANCISCO JOSÉ DEL POZO SERRANO

SIPS - PEDAGOGIA SOCIAL. REVISTA INTERUNIVERSITARIA [1139-1723 (2015) 26, 173-199] TERCERA ÉPOCA 


\section{Notas}

1 Este trabajo se inserta dentro del Plan Nacional de Investigación, Proyecto de Investigación |+D+| denominado "Mujeres reclusas drogodependientes y su reinserción social. Estudio socioeducativo y propuestas de acción“"[Ref. EDU2009-13408], financiado por el Ministerio de Economía y Competitividad (MICCIN) del gobierno español. Asimismo, cabe agradecer el apoyo y participación de la Secretaría General de Instituciones Penitenciarias, a la Consejería de Justicia de la Generalidad de Cataluña, a cada uno de los Centros de cumplimiento de pena estudiados y, a todas las mujeres reclusas por su generosidad en la participación.

\section{CÓMO CITAR ESTE ARTÍCULO / HOW TO CITE THE ARTICLE}

Pozo Serrano, F. J., (2015). Prevención y tratamiento en el ámbito penitenciario: las mujeres reclusas drogodependientes en España. Pedagogía Social. Revista Interuniversitaria, 26 173-199. DOI:10.7179/ PSRI_2015.26.07

Fecha de recepción del artículo / received date: 6.XI.2014

Fecha de revisión del artículo: / reviewed date: 24.XI.2014

Fecha de aceptación final / accepted date: 03.111.2015

\section{DIRECCIÓN DE LOS AUTORES/ AUTHOR'S ADDRESS}

Francisco José del Pozo Serrano: Dpto. de Educación. TIf. (57) (5) 3509509. Ext. 3308. Instituto de Estudios en Educación. Universidad del NorteKm.5 Vía Puerto Colombia - Barranquilla (Colombia. Dirección de correo/e-mail: fdelpozo@uninorte.edu.co

\section{PERFIL ACADÉMICO / ACADEMIC PROFILE}

Francisco José del Pozo Serrano: Educador social, licenciado en historiador del arte y ex coordinador de la Unidad dependiente de madres del centro penitenciario de Albolote (Granada) y Centro de Inserción Social "Matilde Cantos Fernández" (Granada) (2006-2011). Doctor en Ciencias de la Educación con mención internacional y tesis "cum laude" en el programa "Educación Social: Fundamentos y metodologías" por la Universidad de Granada. Ha sido profesor de la Universidad de Castilla la Mancha, Universidad Complutense de Madrid y profesor invitado en el Máster universitario de "Intervención educativa en contextos sociales" de la Universidad Española Nacional a distancia (UNED). Investigador de la Universidad de Granada del Proyecto nacional "Mujeres reclusas drogodependientes y su reinserción social. Estudio socioeducativo y propuestas de acción" [Ref. EDU2009-13408]. Investigador del grupo "Otras: Feminismo en Investigación Social" de la Universidad de Granada. Investigador del Proyecto europeo "El juego de la orquesta” para lugares privados de libertad de la Université Charles de Gaulle3 (Lille. Francia). Actualmente docente del Dpepartamento de Educación en programa de Licenciatura en "Pedagogía Infantil" y la asignatura de "Educación Social" en la Maestría de Educación , tutor de investigación de Maestría y Doctorado en Educación del Instituto de Estudios en Educación de la Universidad del Norte e investigador del grupo "Cognición y Educación". 
